Article

\title{
Synthetic Studies to Help Elucidate the Metabolism of the Preclinical Candidate TBAJ-876-A Less Toxic and More Potent Analogue of Bedaquiline
}

\author{
Peter J. Choi ${ }^{1,2, * \mathbb{C}}$, Daniel Conole ${ }^{1}$, Hamish S. Sutherland ${ }^{1}$, Adrian Blaser ${ }^{1} \mathbb{1}$, Amy S.T. Tong ${ }^{1}$, \\ Christopher B. Cooper ${ }^{3}{ }^{\circ}$, Anna M. Upton ${ }^{3}$, Brian D. Palmer ${ }^{1,2}$ and William A. Denny ${ }^{1,2}{ }^{(B)}$ \\ 1 Auckland Cancer Society Research Centre, School of Medical Sciences, University of Auckland, \\ Private Bag 92019, Auckland 1142, New Zealand; conoledaniel@gmail.com (D.C.); \\ h.sutherland@auckland.ac.nz (H.S.S.); a.blaser@auckland.ac.nz (A.B.); amytong0606@gmail.com (A.S.T.T.); \\ b.palmer@auckland.ac.nz (B.D.P.); b.denny@auckland.ac.nz (W.A.D.) \\ 2 Maurice Wilkins Centre, University of Auckland, Private Bag 92019, Auckland 1142, New Zealand \\ 3 Global Alliance for TB Drug Development, 40 Wall St, New York, NY 10005, USA; \\ christopher.cooper@tballiance.org (C.B.C.); anna.upton@tballiance.org (A.M.U.) \\ * Correspondence: p.choi@auckland.ac.nz
}

Received: 19 February 2020; Accepted: 19 March 2020; Published: 20 March 2020

\begin{abstract}
Bedaquiline is a novel drug approved in 2012 by the FDA for treatment of drug-resistant tuberculosis (TB). Although it shows high efficacy towards drug-resistant forms of TB, its use has been limited by the potential for significant side effects. In particular, bedaquiline is a very lipophilic compound with an associated long terminal half-life and shows potent inhibition of the cardiac potassium hERG channel, resulting in QTc interval prolongation in humans that may result in cardiac arrhythmia. To address these issues, we carried out a drug discovery programme to develop an improved second generation analogue of bedaquiline. From this medicinal chemistry program, a candidate (TBAJ-876) has been selected to undergo further preclinical evaluation. During this evaluation, three major metabolites arising from TBAJ-876 were observed in several preclinical animal models. We report here our synthetic efforts to unequivocally structurally characterize these three metabolites through their independent directed synthesis.
\end{abstract}

Keywords: bedaquiline; TMC207; Sirturo; bedaquiline analogues; TBAJ-876; mycobacterium tuberculosis; tuberculosis; drug development

\section{Introduction}

Tuberculosis (TB) is one of the top ten leading causes of death in the world and is the leading cause of death from a single infectious agent. In fact, TB is more lethal than HIV/AIDS globally [1]. It was estimated TB caused 1.5 million deaths in 2018, with 10 million new cases of TB estimated for that year alone. The often late detection of TB [2], coupled with the need to use long and complex multi-drug treatment regimens to treat it, has led to an alarming increase in cases which are resistant to the standard front-line drugs for drug sensitive TB (i.e., rifamicin, isoniazid, pyrazinamide, and ethambutol). In 2017, about 558,000 people developed TB that was resistant to rifampicin, and of these, $82 \%$ had multidrug-resistant TB (MDR TB), and this proportion has been rising rapidly [1].

The discovery and regulatory approval of the novel antitubercular agent bedaquiline $\mathbf{1}$ (TMC207, Sirturo; Figure 1) has been of great significance within the TB community. It has a unique diarylquinoline (DARQ) structure and a novel mechanism of action (inhibition of the mycobacterial ATP synthase [3]), and has shown significant activity against drug-resistant tuberculosis strains (MDR TB, and XDR TB). When added to standard background therapy used for MDR TB, it demonstrated more rapid bactericidal 
activity than standard therapy alone [4] and was approved by the FDA for treatment of MDR TB in 2012 , making it the first TB drug with a novel mode of action in 40 years. However, bedaquiline does have some significant draw-backs. In a registration trial, bedaquiline showed an increased incidence of death compared to the placebo treatment group, possibly due to several pharmacological factors [5]. It is very lipophilic (measured $\log$ P of 7.25), and binds to fatty tissues in the body and has been associated with an increased incidence of phospholipidosis [6]. This lipophilicity also likely contributes to its long terminal half-life of 5-6 months [7]. It inhibits the cardiac potassium hERG channels to cause QTc interval prolongation (resulting in delayed ventricular repolarization). This is a serious consideration for combination regimens with other anti-TB drugs such as the fluoroquinolones or clofazimine, which also exhibit such cardiovascular side effects [8]. Due to such potential toxicities, the WHO advises caution when using bedaquiline, and recommends that strict monitoring procedures be put in place for patients taking bedaquiline [9].

With such limitations present with bedaquiline, the identification of new analogues with similar or better anti-bacterial potency but lower clogP and diminished inhibition of hERG channel activity would be of tremendous interest. In light of this, an exploration of the diarylquinolines to identify improved second generation analogues of bedaquiline was initiated [10-15]. After extensive drug discovery efforts, TBAJ-876 2 was selected for preclinical evaluation as a more potent, less lipophilic analogue with lower cardiotoxic potential than bedaqiline $\mathbf{1}$ (Table 1) [16].
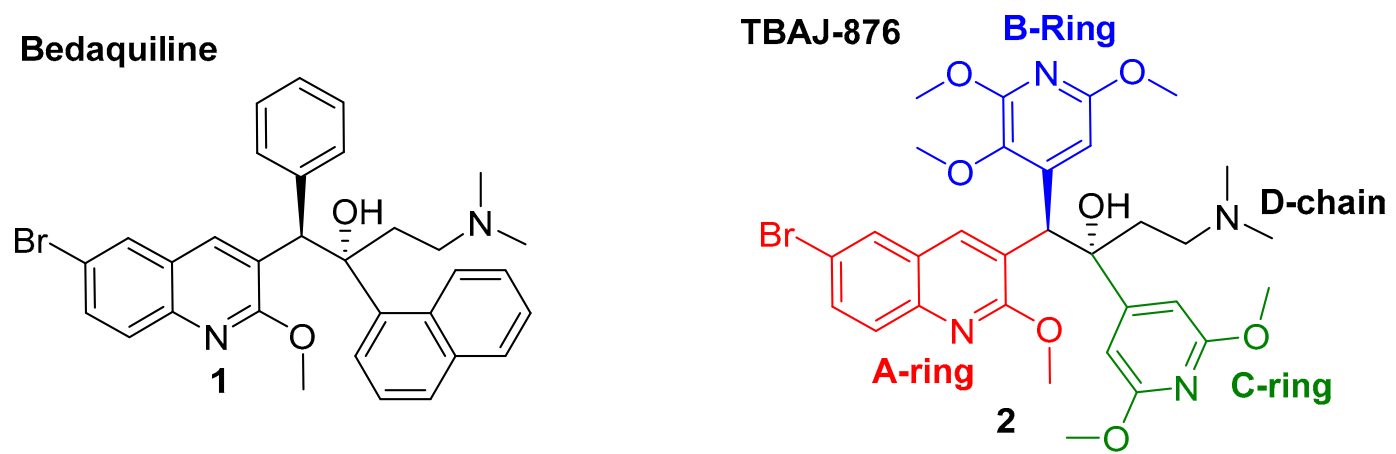

Figure 1. Structure of bedaquiline 1 and preclinical candidate TBAJ-876 2.

Table 1. Physical and biological properties of bedaquiline 1 and TBAJ-876 2.

\begin{tabular}{|c|c|c|}
\hline Property & $\begin{array}{l}\text { Bedaquiline } \\
\text { (1) }\end{array}$ & TBAJ-876 (2) \\
\hline Lipophilicity $(\operatorname{cog} \mathrm{P})^{\mathrm{a}}$ & 7.25 & 5.15 \\
\hline Solubility pH $7.4(\mu \mathrm{M})$ & $<0.06$ & $<0.02$ \\
\hline Mouse PO $\mathrm{t}_{1 / 2}(\mathrm{hr})$ & 44 & 26 \\
\hline $\operatorname{MIC}(\mathrm{MABA})(\mu \mathrm{g} / \mathrm{mL})^{\mathrm{b}}$ & 0.04 & 0.004 \\
\hline MIC (LORA) $(\mu \mathrm{g} / \mathrm{mL})^{b}$ & 0.08 & 0.006 \\
\hline hERG IC $_{50}(\mu \mathrm{M})^{c}$ & 1.6 & $>30$ \\
\hline
\end{tabular}

a clogP calculated by ChemDraw v19.0.0.22. (CambridgeSoft); ${ }^{\mathrm{b}} \mathrm{MIC}_{90}(\mu \mathrm{g} / \mathrm{mL}) ;$ minimum inhibitory concentration for $90 \%$ inhibition of growth of M.tb strain H37Rv, determined under aerobic (replicating; MABA) or non-replicating (LORA) conditions; ${ }^{\mathrm{C}}$ Inhibition of hERG $\left(\mathrm{IC}_{50}\right.$ in $\left.\mu \mathrm{M}\right)$.

The metabolic fate of TBAJ-876 2 was evaluated over the course of several preclinical in vivo studies. In particular, TBAJ-876 2 was administered orally at $10.0 \mathrm{mg} / \mathrm{kg}$ QD to Sprague Dawley rats for 5 days, and plasma samples were obtained at the conclusion of the final dosing period. While the majority of the test article remained intact, several circulating metabolites were identified in pooled rat plasma, and their structures were tentatively assigned by mass spectrometry fragmentation. From this in vivo experiment, three major metabolites were identified and assigned structures 3-5 as shown in Scheme 1 . There were no species difference between rat and mouse metabolism of TBAJ-876 and rats were selected as they were well represented across various preclinical studies. 


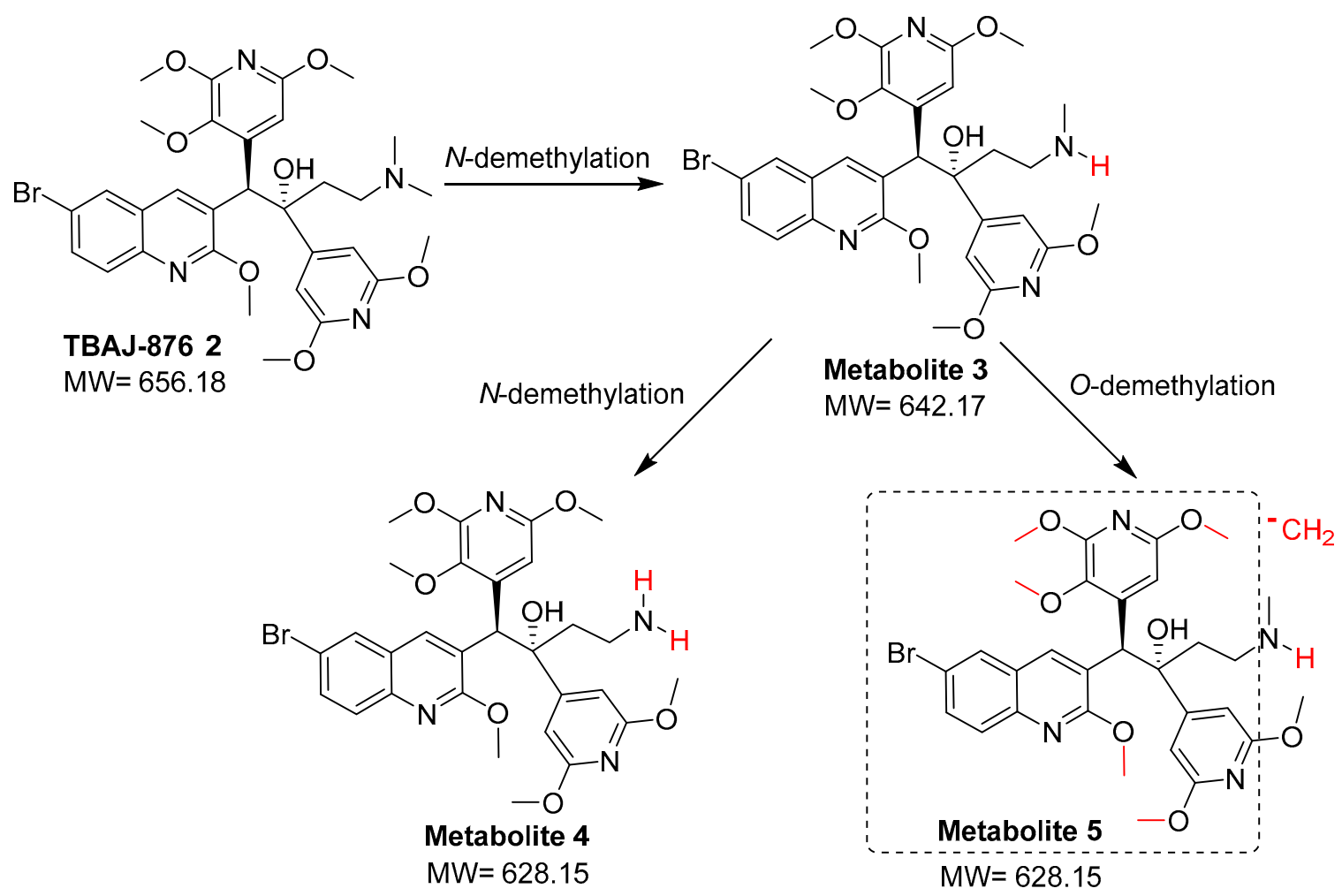

Scheme 1. Proposed metabolic pathways of TBAJ-876 2 in rat plasma.

Metabolite 3 is conjectured to arise from mono-demethylation in the dimethylamino sidechain (D-chain) of TBAJ-876 2 while metabolite 4 represents the bis-demethylated analogue. Metabolite 5 had two sites of demethylation, mono-demethylated in the D-chain, together with a second mono-demethylation of one of the other methoxy groups in the molecule. Such metabolites are important factors to consider when conducting drug safety studies for new pharmaceutical drugs. The identification and characterization of major metabolites of TBAJ-876 would help establish their impacts on safety and efficacy of TBAJ-876 for further preclinical studies. Synthetic studies towards these possible metabolites to help elucidate the metabolism of TBAJ-876, and to provide authentic standards for mass spectrometry and for metabolite profiling studies, are outlined below.

\section{Results and Discussion}

\subsection{Synthesis of Metabolite 3}

The chemistry to access metabolite $\mathbf{3}$ is shown in Scheme 2. 
<smiles></smiles>

Scheme 2. Proposed synthesis of Metabolite 3.

The A/B unit 7 [14] would be coupled with an appropriately protected Mannich base 8 to give 6 , which, following protecting group removal would yield the desired metabolite 3 . It was imperative that the protecting group for Mannich base 8 be acid labile, as base labile protecting groups would be difficult to remove cleanly. Diarylquinoline analogues of bedaquiline are unstable under basic conditions leading to retro-aldol reactions and reversion to their respective starting units [17]. The protecting group would also need to be stable enough to survive the LDA used in the standard DARQ coupling conditions. After several trials, dimethoxybenzyl (DMB) was chosen as the most appropriate protecting group (other acid labile protecting groups such as BOC and silyl protecting groups had failed to yield Mannich base 8). Commercially available acid $\mathbf{9}$ was converted to $\mathbf{1 0}$ using sodium methoxide at $130{ }^{\circ} \mathrm{C}$ for $18 \mathrm{~h}$ (Scheme 3). It was important to form the sodium methoxide in situ using methanol and sodium metal as premade commercial grade reagents gave varying results including incomplete reaction and mono displacement of methoxide. 10 was converted to the Weinreb amide 11 using oxalyl chloride, followed by addition of hydroxylamine hydrochloride salt and pyridine. With 11 in hand, it was added to vinyl magnesium bromide to provide vinyl ketone intermediate 12 in situ. The addition of amine 14 and water gave a $68 \%$ yield of the desired protected Mannich base 15 .

Gratifyingly, Mannich base 15 underwent coupling with A/B unit 7 under standard DARQ coupling conditions [10-12] to give coupled product DARQ 16 in $69 \%$ yield as a $1: 1$ mixture of diastereomers (Scheme 4). The direct removal of the DMB protecting group using various acidic conditions (TFA, 2M HCl) was unsuccessful. Instead, we resorted to converting DMB group to trifluoroacetate 17 by reacting 16 with TFAA in DCM and then removing the trifluoroacetate group using a mild base such as cesium carbonate [18] despite our previous experience that this could lead to retro-coupling. Treatment of $\mathbf{1 7}$ in $\mathrm{MeOH}$ with cesium carbonate at r.t. did indeed cause retro-coupling to yield A/B unit 7 with no signs of desired metabolite 3. However, after the careful optimisation of the reaction conditions by carrying out the reaction at $-20{ }^{\circ} \mathrm{C}$ gave the desired metabolite 3 with minimal retro-coupling. 
<smiles>C=CC(=O)c1cc(OC)nc(OCC(C)C#CC(C)C)c1</smiles><smiles>CNCc1ccc(OC)cc1OCC#CCOc1ccc(OC)c(OC)c1</smiles>

Scheme 3. Synthesis of Mannich base 15. Reagents and conditions: (i) $\mathrm{NaOMe}, \mathrm{MeOH}, 130{ }^{\circ} \mathrm{C}, 18 \mathrm{~h}$, $87 \%$; (ii) $(\mathrm{COCl})_{2}$, cat. DMF, DCM, then $\mathrm{MeNH}(\mathrm{OMe}) \cdot \mathrm{HCl}$, pyridine, $20^{\circ} \mathrm{C}, 18 \mathrm{~h}, 83 \%$; (iii) vinylMgBr, THF, $0{ }^{\circ} \mathrm{C}$ then $14, \mathrm{H}_{2} \mathrm{O}, 68 \%$; (iv) $\mathrm{MeNH}_{2}, \mathrm{NaBH}_{4}, \mathrm{MeOH}, 2 \mathrm{~h}, 100 \%$.<smiles>COc1ccc(OC)c(CN(C)CCC(C)(c2cc3cc(Br)ccc3nc2OC)C(c2cc(OC)nc(OC)c2OC)c2c(Cc3cc(OC)nc(OC)c3OC)cc(Cc3cc(OC)nc(OC)c3OC)cc2OC)c1</smiles>

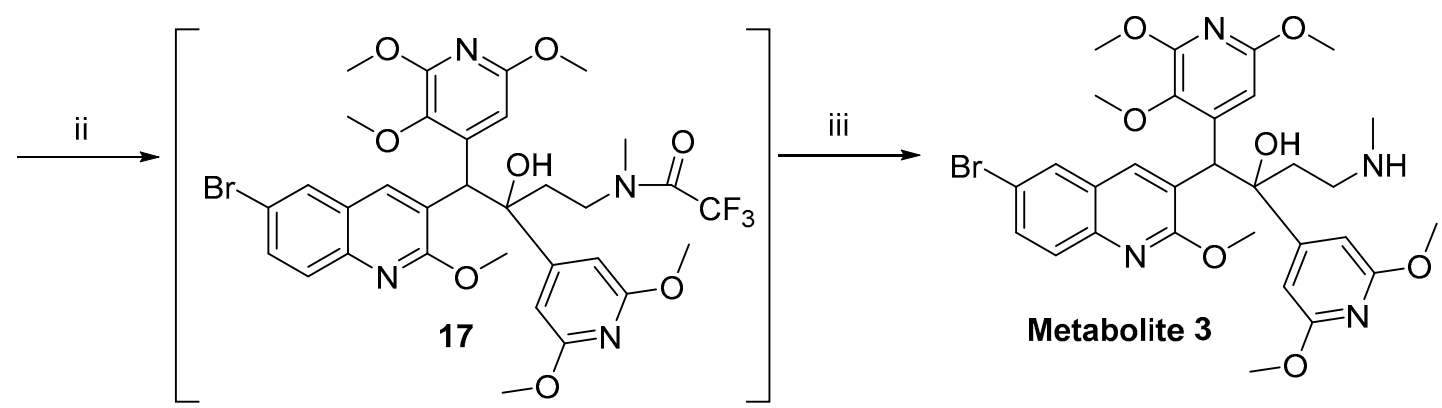

Scheme 4. Synthesis of metabolite 3. Reagents and conditions: (i) LDA, THF, $-75^{\circ} \mathrm{C}, 1.5 \mathrm{~h}$ then $\mathbf{1 5}$, $-75{ }^{\circ} \mathrm{C}, 5 \mathrm{~h}, 69 \%$; (ii) TFAA, DCM, $1 \mathrm{~h}$; (iii) $\mathrm{Cs}_{2} \mathrm{CO}_{3}, \mathrm{MeOH},-20{ }^{\circ} \mathrm{C}, 12 \mathrm{~h},(49 \%)$.

\subsection{Synthesis of Metabolite 4}

The chemistry to access metabolite 4 is outlined in Scheme 5 below. 
<smiles>C=CCOc1cc(C(O)(CCN)C(c2cc(OC)nc(OC)c2OC)c2cc(OC)nc(OC)c2OC)cc(OCC)n1</smiles><smiles>[3H]c1c(Cc2cc3cc(Br)ccc3nc2OC)cc(OC)nc1OC</smiles>

Scheme 5. Proposed synthesis of metabolite 4 .

The synthetic plan to access metabolite 4 was similar to that for metabolite 3 , but instead of using mono-protected Mannich base 15, a suitably bis-protected Mannich base 19 was needed (Scheme 5). The benzophenone imine protected Mannich base $\mathbf{2 1}$ was considered to be a suitable protecting group as it could be readily cleaved in acidic conditions and yet also be stable during the coupling reaction conditions. Synthesis began with Weinreb amide 11, to which was added vinyl magnesium bromide to form vinyl ketone intermediate 12, which was then added to benzophenone imine $\mathbf{2 0}$ followed by addition of water (Scheme 6). However, instead of generating desired ketone 21, it formed two major by-products 22 and 23 . This could be explained by the cleaved $\mathrm{N}, \mathrm{O}$-dimethylhydroxylamine in the reaction mixture from $\mathbf{1 1}$ reacting with vinyl ketone intermediate $\mathbf{1 2}$ to yield by-product 22.23 is a quaternary salt formed from another equivalent of vinyl ketone 12 being added to by-product 22 .<smiles>[Z17]c1cc(C(=O)CCN=C(c2ccccc2)c2ccccc2)cc(OC)n1</smiles>

Scheme 6. Attempted synthesis of intermediate 21. Reagents and conditions: (i) vinylMgBr, $\mathrm{THF}, 0{ }^{\circ} \mathrm{C}$ then $20, \mathrm{H}_{2} \mathrm{O}$. 
This problem was overcome by isolating the vinyl ketone intermediate $\mathbf{1 2}$ from the reaction mixture instead of using it in situ, hence avoiding the presence of competing nucleophiles, such as cleaved N,O-dimethylhydroxylamine. By using a modified reported procedure [19], Mannich base 24 [14] was treated with methyl iodide for $72 \mathrm{~h}$ to form quaternary ammonium iodide salt which was washed with water and subsequent elimination liberated pure vinyl compound $\mathbf{1 2}$ (Scheme 7). With $\mathbf{1 2}$ isolated, it was dissolved in THF, added benzophenone imine $\mathbf{2 0}$ and stirred at r.t. for $\mathbf{3 0} \mathrm{min}$. After work up and silica chromatography, desired Mannich base 21 was isolated along with $~ 10 \%$ of benzophenone 25 which could be removed during purification on the next step. Several other protecting groups were also investigated, however were unsuccessful in forming bis-BOC protected or bis-DMB protected Mannich base 19.

Compound 21 was then coupled successfully with A/B unit 7 to yield DARQ 26. Removal of benzophenone imine protecting group was achieved using hydroxylamine and sodium carbonate in DCM to give metabolite 4 in $53 \%$ yield.<smiles>[Z6]c1nc(OC)cc(C(=O)c2cc(OC)nc(OC)c2)c1CC(=O)c1cc(OC)nc(OC)c1CCC(=O)c1cc(OC)nc(OC)c1</smiles>

Scheme 7. Synthesis of intermediate 21 and metabolite 4. Reagents and conditions: (i) MeI, DCM, $14 \mathrm{~h}$, $41 \%$; (ii) benzophenone imine 20, THF, $0.5 \mathrm{~h}, 68 \%$; (iii) LDA, THF, $-75{ }^{\circ} \mathrm{C}, 1.5 \mathrm{~h}$ then $21,-75{ }^{\circ} \mathrm{C}, 5 \mathrm{~h}$, $35 \%$; (iv) $\mathrm{NH}_{2} \mathrm{OH}-\mathrm{HCl}, \mathrm{Na}_{2} \mathrm{CO}_{3}, \mathrm{DCM}, 48 \mathrm{~h}, 53 \%$. 


\subsection{Synthesis of Metabolite 5}

The exact structure of metabolite 5 was unknown. From mass spectral evidence, it had two sites of demethylation, being mono-demethylated in the D-chain and mono-demethylated somewhere in one of the methoxy groups in the molecule. This leaves five possible sites of demethylation and the possible structures for metabolite 5 are outlined in Figure 2.<smiles>CNCCC(O)(c1cc(OC)nc(OC)c1)C(c1cc(OC)nc(OC)c1OC)c1cc(OC)nc2ccc(Br)cc12</smiles>

Figure 2. Five possible structures of metabolite 5 .

\subsubsection{Metabolite 5A}

Metabolite 5A has a demethylated D-chain with a demethylation at the methoxy group on the 3-position of the pyridine B-ring (Scheme 8). Metabolite 5A was synthesized from suitably protected A/B unit 27, which was coupled with the previously synthesized Mannich base $\mathbf{1 5 .}$ 
<smiles>COc1cc(C(=O)CCN(C)Cc2cc(OC)c(Cc3cc(OC)nc(OC)c3[O-])c(Cc3cc4cc(Br)ccc4nc3OC)c2OC)cc(OC)n1</smiles>

Scheme 8. Proposed synthesis of metabolite 5A.

Synthesis of A/B unit 27 began with boronic acid $\mathbf{3 0}$ which was converted to alcohol $\mathbf{3 1}$ in $90 \%$ yield (Scheme 9). Alcohol 31 was protected with an ethoxymethyl ether (EOM) protecting group to yield 32. Formylation of $\mathbf{3 2}$ gave aldehyde $\mathbf{3} 3$ which was reduced to alcohol $\mathbf{3 4}$ using sodium borohydride in good yields. The conversion of alcohol 34 to a mesylate group which was displaced by lithium bromide furnished bromide 35 . Suzuki reaction between bromide 35 and boronic acid 28 produced desired A/B unit 36. It was important to carry out the Suzuki reaction at $35^{\circ} \mathrm{C}$ as higher temperatures $\left(80^{\circ} \mathrm{C}\right)$ led to degradation of products. With 36 in hand, it was coupled with Mannich base $\mathbf{1 5}$ to give 37 as 1:1 mixture of diastereomers in 69\% yield. The subsequent removal of the DMB-protecting group using previously established chemistry followed by the removal of the EOM-protecting group using $1 \mathrm{M} \mathrm{HCl}$ in dioxane yielded desired metabolite $5 \mathbf{A}$. 
<smiles>CC#CCOc1ccc(O)c(OCC#CC)n1</smiles><smiles>CCOCOc1c(CO)cc(OC)nc1OCCCOCOc1c(CBr)cc(OC)nc1OC</smiles>

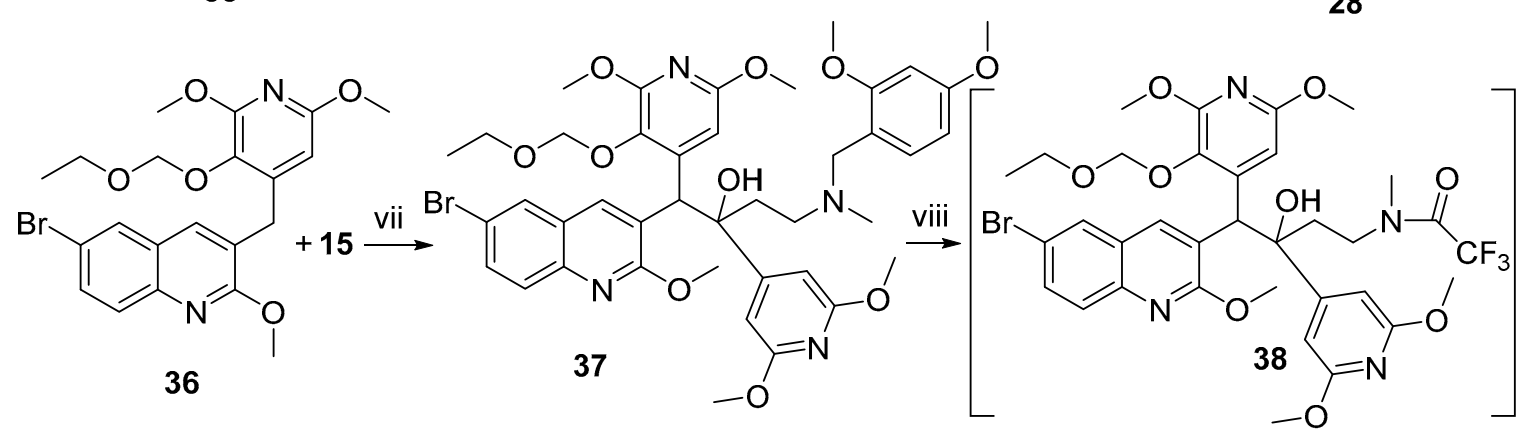

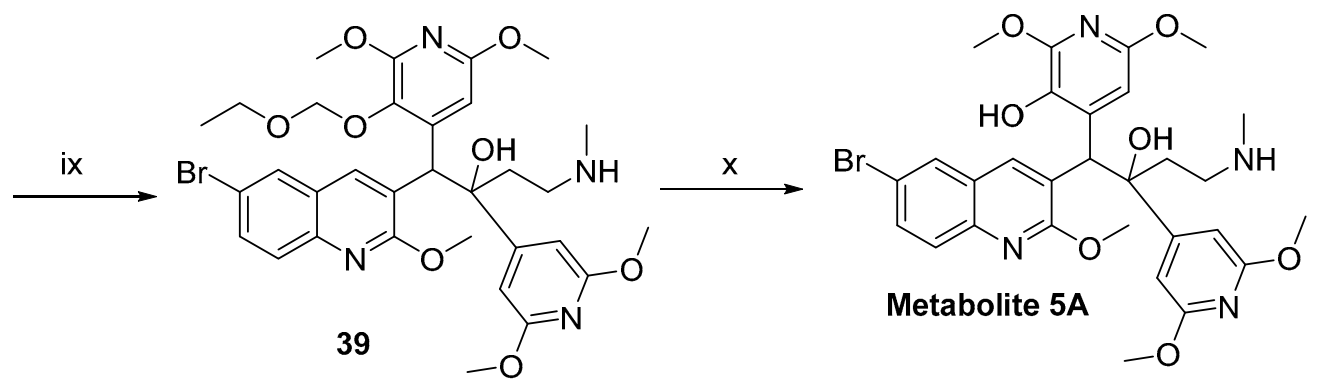

Scheme 9. Synthesis of key intermediate 36 and metabolite 5A. Reagents and conditions: (i) 32\% peracetic acid in acetic acid, THF, $2 \mathrm{~h}, 90 \%$; (ii) $\mathrm{NaH}$ (60\% in mineral oil), chloromethyl ethyl ether, DMF, 2 h, 93\%; (iii) LDA, THF, DMF, 3 h 51\%; (iv) $\mathrm{NaBH}_{4}, \mathrm{MeOH}, 2 \mathrm{~h}, 93 \%$; (v) MsCl, DCM, $0.5 \mathrm{~h}$ then LiBr, acetone, $100{ }^{\circ} \mathrm{C}$, 99\%; (vi) $\mathrm{Cs}_{2} \mathrm{CO}_{3}, \mathrm{Pd}\left(\mathrm{PPh}_{3}\right)_{4}, \mathrm{PhMe} / \mathrm{DMF}, 35^{\circ} \mathrm{C}$ (sealed tube), $1 \mathrm{~h}, 76 \%$; (vii) LDA, $\mathrm{THF},-75^{\circ} \mathrm{C}, 1.5 \mathrm{~h}$ then $15,-75^{\circ} \mathrm{C}, 5 \mathrm{~h}, 69 \%$; (viii) TFAA, DCM, $1 \mathrm{~h}$; (ix) $\mathrm{Cs}_{2} \mathrm{CO}_{3}, \mathrm{MeOH},-20{ }^{\circ} \mathrm{C}, 72 \mathrm{~h}$, $49 \%$; (x) $1 \mathrm{M} \mathrm{HCl}$, dioxane, $24 \mathrm{~h}$, Isomer A: $20 \%$, Isomer B: $27 \%$.

\subsubsection{Metabolite 5B}

Metabolite 5B has a demethylated D-chain with a demethylation at the methoxy group on the 6-position of the pyridine B-ring (Scheme 10). Metabolite 5B was synthesized from suitably protected $\mathrm{A} / \mathrm{B}$ unit $\mathbf{4 0}$ which was coupled with previously synthesized Mannich base 15 . A selective mono-demethylation of $\mathrm{A} / \mathrm{B}$ unit 7 was proposed to yield 41 as 6-methoxy group adjacent to the nitrogen of the B-ring in 7 would be activated. Although methoxy group at the 2-position is also activated, steric hindrance from methoxy group at the 3-position would hinder demethylation from occurring. 
<smiles>[Z]Oc1nc2ccc(Br)cc2cc1Cc1cc(OC)nc(OC)c1OCC(=O)Oc1cc(Cc2cc3cc(Br)ccc3nc2OC)c(Cc2cc(OC)nc(OC)c2OC)cc1Cc1cc(C(=O)CCN(C)Cc2ccc(OC)cc2OC)cc(OC)n1</smiles>

Scheme 10. Proposed synthesis of metabolite 5B.

The selective demethylation of 7 was achieved using lithium chloride and pTSA in DMF [20] (Scheme 11). This reaction condition was a mild alternative which gave a far superior yield $(90 \%)$ compared to $\mathrm{BBr}_{3}(15 \%)$, a common demethylation reagent. The structure of 41 was confirmed by ${ }^{1} \mathrm{H}$ NMR and 2D NOESY experiments. A/B unit 7 shows a clear NOE signal between the $5-\mathrm{H}$ and the adjacent $\mathrm{CH}_{3}$ on the 6-methoxy group in the pyridine B-ring while for product 41 , NOE signal clearly disappears, confirming it is structure $\mathbf{4 1}$ as this signal would still be present if it was structure $\mathbf{4 2}$. It was pleasing demethylation had occurred selectively at the desired 6-position of the pyridine B-ring with excellent yields. With structure of $\mathbf{4 1}$ confirmed, it was dissolved in DCM, added DIPEA and chloromethyl ethyl ether and stirred at r.t. for $18 \mathrm{~h}$ to give EOM protected $\mathrm{A} / \mathrm{B}$ unit 43 in adequate yields. 43 was submitted to our standard coupling reaction conditions with DMB protected Mannich base 15 to yield DARQ 44 . Using similar chemistry as the previous metabolites, treatment of 44 with TFAA led to deprotection of both the EOM and the DMB group to furnish trifluoroacetamide 45. Subsequent mild basic hydrolysis conditions yielded metabolite $5 \mathrm{~B}$ as pure high and low Rf diastereomers. 


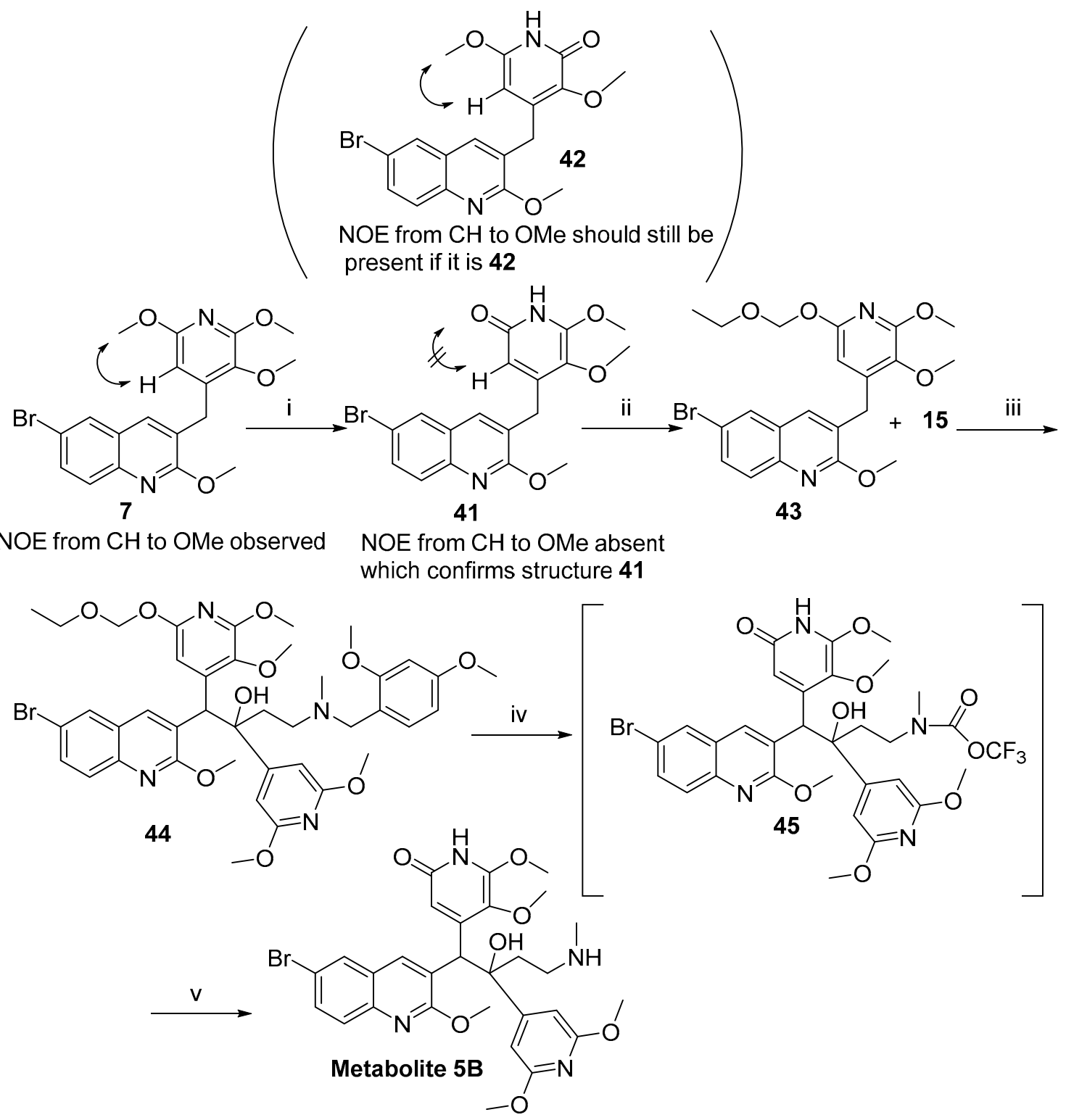

Scheme 11. Synthesis of key intermediate 43 and metabolite 5B. Reagents and conditions: (i) $\mathrm{LiCl}$, pTSA, DMF, $120^{\circ} \mathrm{C}, 1 \mathrm{~h}, 90 \%$; (ii) DIPEA, chloromethyl ethyl ether, DCM, $18 \mathrm{~h}, 49 \%$; (iii) LDA, THF, $-75{ }^{\circ} \mathrm{C}, 1.5 \mathrm{~h}$ then $15,-75{ }^{\circ} \mathrm{C}, 5 \mathrm{~h}, 83 \%$; (iv) TFAA, DCM, $1 \mathrm{~h}$; (v) $\mathrm{Cs}_{2} \mathrm{CO}_{3}, \mathrm{MeOH},-20{ }^{\circ} \mathrm{C}, 48 \mathrm{~h}$, Isomer A: $19 \%$, Isomer B: $21 \%$.

\subsubsection{Metabolite 5C}

Metabolite $5 \mathrm{C}$ has a demethylated $\mathrm{D}$ side chain with mono demethylation on the methoxy group at the 2 position in the B-ring (Scheme 12). Metabolite 5C was accessed from a coupling reaction between suitably protected A/B unit 46 with Mannich base 15 . A/B unit 46 could be synthesized from bromide 47 which would undergo a Suzuki reaction with boronic acid 28. 
<smiles>COc1ccc(CN(C)CCC(=O)c2cc(OC)nc(OC)c2)c(OC)c1</smiles>

Scheme 12. Proposed synthesis of metabolite 5C.

The synthesis of suitably protected bromide 47 began with commercially available pyridine 48 , which underwent protection with chloromethyl ethyl ether to yield 49 (Scheme 13). Formylation of 49 with $\mathrm{N}$-formylpiperidine gave $\mathbf{5 0}$ followed by removal of EOM protecting group and methylation using iodomethane gave aldehyde 52 . Reactive aldehyde functionality needed to be protected before $\mathrm{N}$-oxide chemistry could be attempted. Aldehyde 52 was protected with 1,2-ethanediol and pyridinium tosylate to give dioxalane 53 in good yields. With aldehyde protected, oxidation to $N$-oxide using $m$-CPBA gave 54 in 70\% yield. Upon refluxing 54 in acetic anhydride, it gave 55 in $71 \%$ yield. Dioxalane protecting group and acetate group was removed using trifluoroacetic acid to yield desired aldehyde $\mathbf{5 6}$.

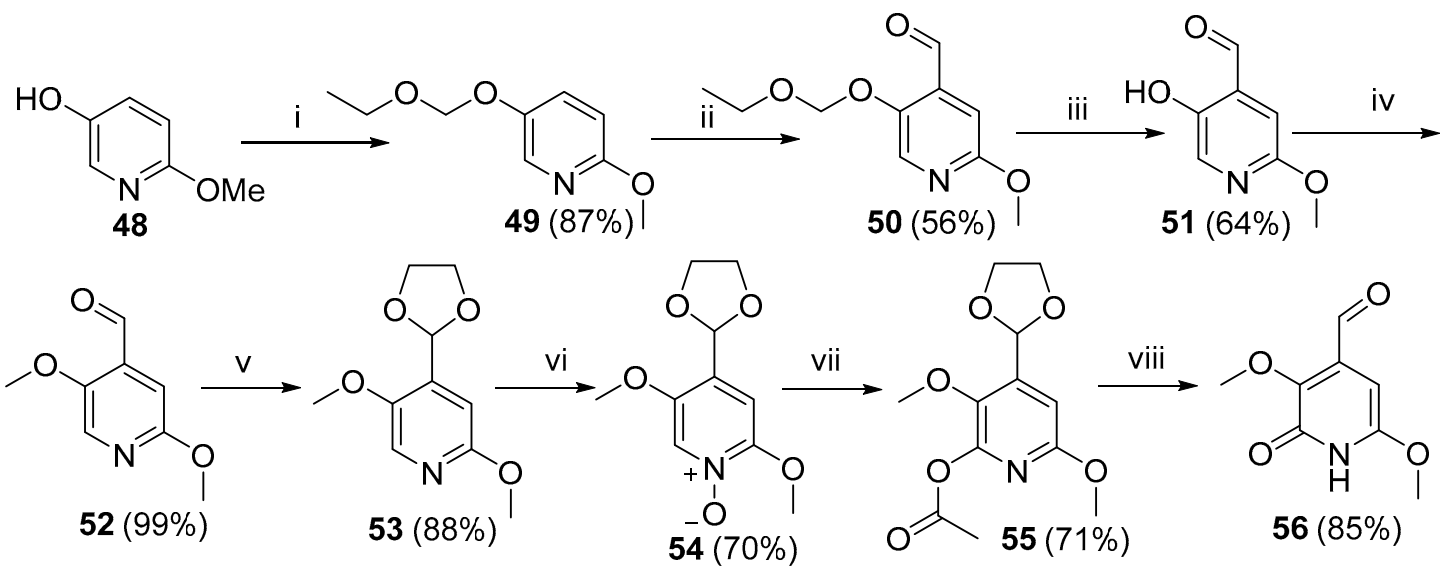

Scheme 13. Synthesis of intermediate 56. Reagents and conditions: (i) $\mathrm{NaH}$, chloromethyl ethyl ether, DMF, $2 \mathrm{~h}, 87 \%$; (ii) LDA, THF, $0{ }^{\circ} \mathrm{C}, 3 \mathrm{~h}$ then $n$-formylpiperidine, $56 \%$; (iii) $3 \mathrm{M} \mathrm{HCl}, \mathrm{THF}, 0{ }^{\circ} \mathrm{C}, 3 \mathrm{~h}, 64 \%$; (iv) $\mathrm{K}_{2} \mathrm{CO}_{3}$, MeI, DMF, $0{ }^{\circ} \mathrm{C}, 3 \mathrm{~h}, 99 \%$; (v) 1,2-ethanediol, PPTS, PhMe, $0{ }^{\circ} \mathrm{C}, 4 \mathrm{~h}, 88 \%$; (vi) $m$-CPBA, $\mathrm{DCM}, 18 \mathrm{~h}, 70 \%$; (vii) $\mathrm{Ac}_{2} \mathrm{O}, 120^{\circ} \mathrm{C}, 4 \mathrm{~h}, 71 \%$; (viii) $\mathrm{TFA}, \mathrm{CHCl}_{3}, 18 \mathrm{~h}, 85 \%$.

The next step was EOM protection of 56 (Scheme 14). Using our standard EOM protection procedure, 56 was dissolved in DCM and added DIPEA and chloromethyl ethyl ether. This reaction gave a mixture of EOM-protected products 57 and 58 where EOM alkylation had occurred on both the nitrogen and the oxygen of the pyridone 56 . $N$-alkylation was favoured yielding 4:1 ratio of 58:57. (Table 2, condition 1). Although it did not matter which position the protecting group went as it would 
be removed in the final step to give the same product, we ideally wanted $O$-protection (57) as similar $O$-protected A/B units (46, Scheme 12) were known to undergo successful DARQ coupling reactions.

Interestingly, solvent polarity had a huge influence on the ratio of $O$ and $N$-alkylated products being formed. The product formation of $O$-alkylation and $N$-alkylation could be reversed by using a range of solvents with different polarities. Using a non-polar solvent such as benzene (condition 2) promoted more $N$-alkylation 58 over $O$-alkylation 57 (9.5:5) while carrying out the reaction with a polar solvent like DMF promoted more $O$-alkylation 57 over $N$-alkylation 58 (4:1). The addition of silver carbonate to form silver salt of 2-pyridones, which is reported to promote O-alkylation under non-polar solvents [21] did not yield any $O$-alkylated product, instead only yielding $N$-alkylated product 58 (conditions 4 and 5).<smiles>COc1cc(C=O)c(OC)c(=O)[nH]1</smiles>

56<smiles>CCOCOc1nc(OC)cc(C=O)c1OC</smiles><smiles>CCOCn1c(OC)cc(C=O)c(OC)c1=O</smiles>

Scheme 14. Synthesis of intermediates 57 and 58.

Table 2. Summary of conditions explored for protection of $\mathbf{5 6}$ with chloromethyl ethyl ether.

\begin{tabular}{ccccc}
\hline & Solvent & Base, Additives & Time & Product Ratio (57:58) \\
\hline 1 & DCM & DIPEA & $24 \mathrm{~h}$ & $1: 4$ \\
\hline 2 & Benzene & DIPEA & $24 \mathrm{~h}$ & $0.5: 9.5$ \\
\hline 3 & DMF & DIPEA & $24 \mathrm{~h}$ & $4: 1$ \\
\hline 4 & Benzene & $\mathrm{Ag}_{2} \mathrm{CO}_{3}$ & $24 \mathrm{~h}$ & $\mathbf{5 8}$ only \\
\hline 5 & Benzene & $\mathrm{Ag}_{2} \mathrm{CO}_{3}$, DIPEA & $24 \mathrm{~h}$ & $\mathbf{5 8}$ only \\
\hline
\end{tabular}

With both 57 and 58 in hand, using similar chemistry as before, they were successfully modified to A/B units 65 and 61 respectively (Schemes 15 and 16). However only O-alkylated A/B unit 65 underwent a successful coupling reaction with Mannich base 15 to yield 66 (Scheme 16). A/B unit 61 did form the characteristic dark-purple/wine coloured reaction mixture once LDA was added, which suggested the successful formation of anion at the benzylic position of $\mathbf{6 1}$ (a common phenomenon in most DARQ coupling reactions). However, it is presumed the benzylic anion formed is stabilized by the changed electronics in the B-ring to prevent reaction with Mannich base 15. Failed coupling reactions were commonly observed with A/B units with B-rings which stabilized the anion formed at the benzylic position. 
<smiles>CCOCn1c(OC)cc(C=O)c(OC)c1=O</smiles><smiles>CCOCn1c(OC)cc(Cc2cc3cc(Br)ccc3nc2OC)c(OC)c1=O</smiles>

59 60

61

$\left[\begin{array}{l}\mathrm{Br} \\ \mathrm{B}\end{array}\right.$<smiles>CCOCn1c(OC)cc(Cc2cc3cc(Br)ccc3nc2OC)c(OC)c1=O</smiles><smiles>[Y4][B][B]c1ccc2nc(OC)c(C(c3cc(OC)n(COCC)c(=O)c3OC)C(C)(CCN(C)Cc3ccc(OC)cc3OC)Cc3cc(OC)nc(OC)c3)cc2c1</smiles>

Scheme 15. Synthesis of intermediate 61 and attempted coupling reaction with 15. Reagents and conditions: (i) $\mathrm{NaBH}_{4}, \mathrm{MeOH}, 2 \mathrm{~h}, 98 \%$; (ii) $\mathrm{MsCl}, \mathrm{DCM}, 0.5 \mathrm{~h}$ then $\mathrm{LiBr}$, acetone, $100{ }^{\circ} \mathrm{C}, 93 \%$; (iii) $\mathrm{Cs}_{2} \mathrm{CO}_{3}, \mathrm{Pd}\left(\mathrm{PPh}_{3}\right)_{4}, \mathrm{PhMe} / \mathrm{DMF}, 35^{\circ} \mathrm{C}$ (sealed tube), $1 \mathrm{~h}, 61 \%$; (iv) LDA, THF, $-75^{\circ} \mathrm{C}, 1.5 \mathrm{~h}$ then 15 , $-75^{\circ} \mathrm{C}, 5 \mathrm{~h}$.

Gratifyingly, A/B unit 65 was successfully coupled with 15 to yield DARQ 66. Following established chemistry as for the previous metabolites, the DMB group deprotection was carried out to give trifluoroacetamide 67 followed by DARQ 68. Final removal of EOM group was achieved using anhydrous $2 \mathrm{M} \mathrm{HCl}$ in diethyl ether to give metabolite $5 \mathrm{C}$ as 1:1 mixture of diastereomers (isomer $\mathrm{A}$ ) and some as pure low Rf diastereomers (isomer B). 
<smiles>CCOCOc1nc(OC)cc(C=O)c1OC</smiles>

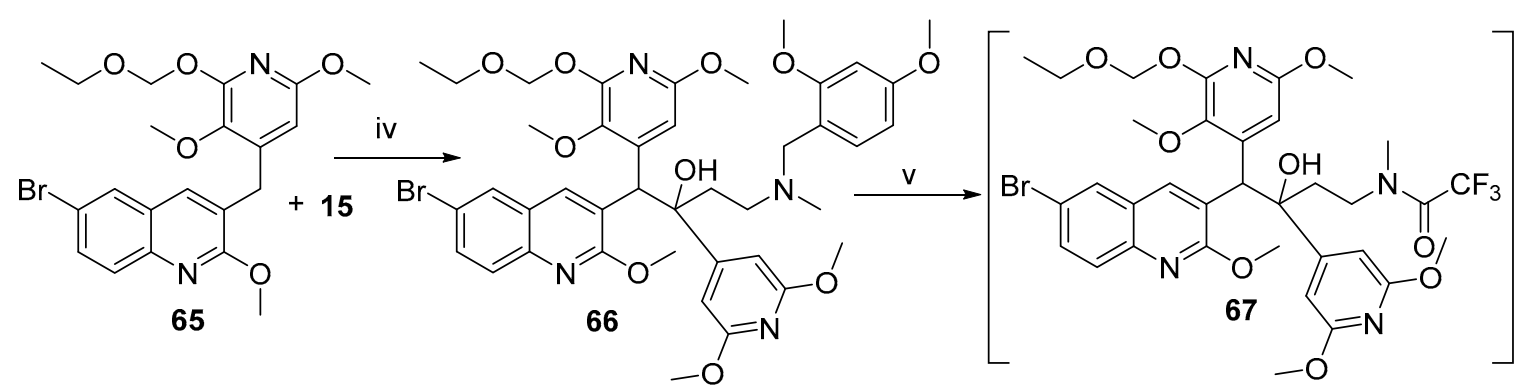<smiles>CCOCOc1nc(OC)cc(C(c2cc3cc(Br)ccc3nc2OC)C(O)(CCNC)c2cc(OC)nc(OC)c2)c1OC</smiles>

Scheme 16. Synthesis of key intermediate 65 and metabolite 5C. Reagents and conditions: (i) $\mathrm{NaBH}_{4}$, $\mathrm{MeOH}, 2 \mathrm{~h}, 92 \%$; (ii) $\mathrm{MsCl}, \mathrm{DCM}, 0.25 \mathrm{~h}$ then $\mathrm{LiBr}$, acetone, $0{ }^{\circ} \mathrm{C}, 98 \%$; (iii) $\mathrm{Cs}_{2} \mathrm{CO}_{3}, \mathrm{Pd}\left(\mathrm{PPh}_{3}\right)_{4}$, $\mathrm{PhMe} / \mathrm{DMF}, 50{ }^{\circ} \mathrm{C}$ (sealed tube), $1 \mathrm{~h}, 81 \%$; (iv) LDA, THF, $-75{ }^{\circ} \mathrm{C}, 1.5 \mathrm{~h}$ then $\mathbf{1 5},-75{ }^{\circ} \mathrm{C}, 5 \mathrm{~h}, 59 \%$; (v) TFAA, DCM, $1 \mathrm{~h}$; (vi) $\mathrm{Cs}_{2} \mathrm{CO}_{3}, \mathrm{MeOH},-20^{\circ} \mathrm{C}, 48 \mathrm{~h}, 67 \%$; (vii) $2 \mathrm{M} \mathrm{HCl}$ in $\mathrm{Et}_{2} \mathrm{O}, 0{ }^{\circ} \mathrm{C}, 0.5 \mathrm{~h}$, Isomer $\mathrm{A}$ : $54 \%$, Isomer B: $23 \%$.

Comparison of ${ }^{1} \mathrm{H}$ NMR run in deuterated chloroform of $\mathrm{A} / \mathrm{B}$ units 36,43 and 65 which were used to synthesize its corresponding metabolites $5 \mathrm{~A}, 5 \mathrm{~B}$ and $5 \mathrm{C}$, respectively, showed a clear difference between the ${ }^{1} \mathrm{H}$ NMR spectrums (Figure 3). A close up of the 3.7 to $5 \mathrm{ppm}$ region showed a clear distinction in the positions of the three methoxy peaks and the position of the benzylic $\mathrm{CH}_{2}$ group. It was comforting to confirm that the three $\mathrm{A} / \mathrm{B}$ units were indeed distinguishable with each isomer synthesized from its corresponding starting material. 


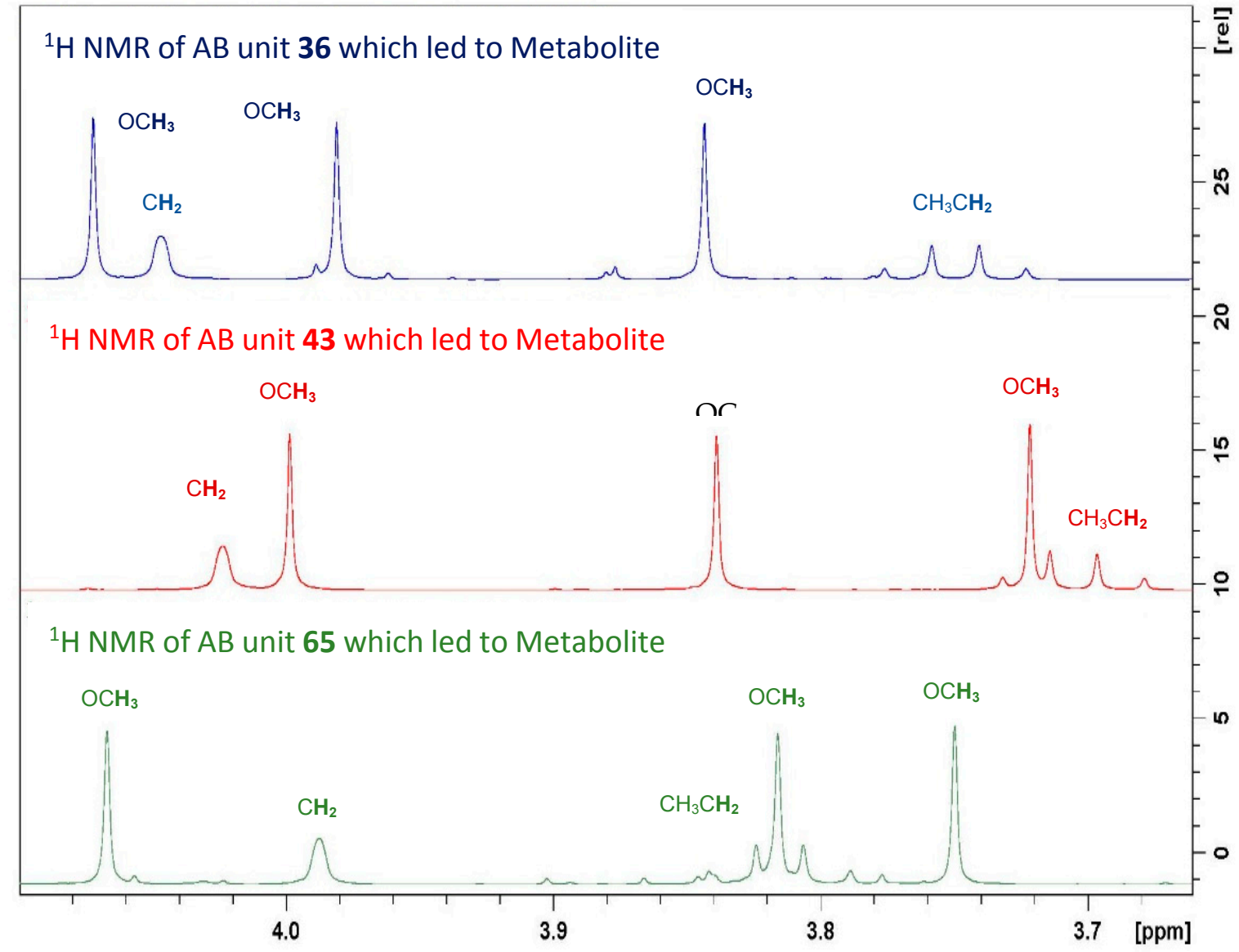

Figure 3. ${ }^{1} \mathrm{H}$ NMR spectrums of A/B units 36,43 and 65 which were used to synthesize metabolites $5 \mathrm{~A}$, 5B and 5C respectively.

\subsubsection{Metabolite 5D}

Metabolite 5D was synthesized from coupling reaction between previously synthesized A/B unit 7 and a suitably bis-protected Mannich base 69 (Scheme 17).

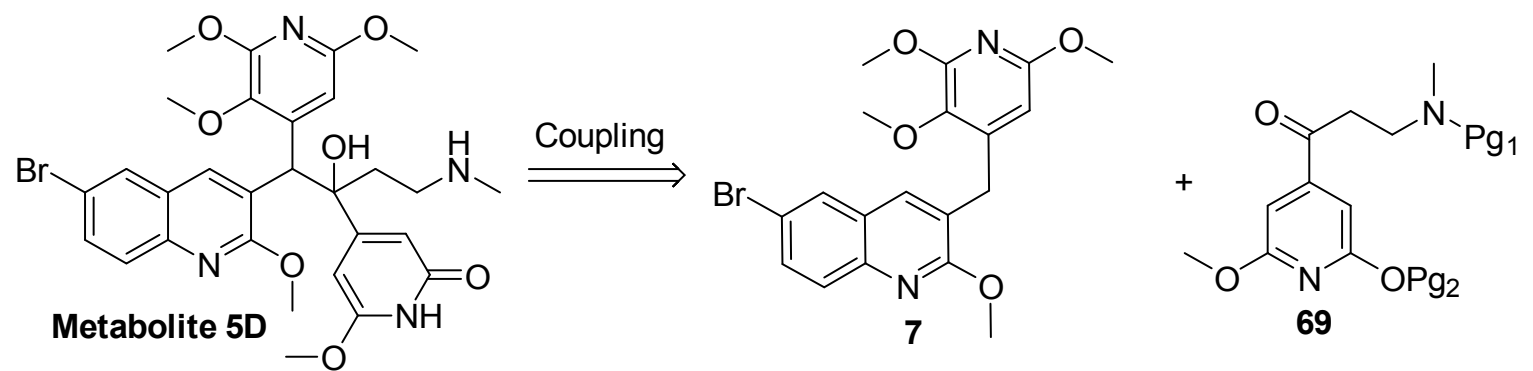

Scheme 17. Proposed synthesis of metabolite 5D.

Synthesis of suitably protected Mannich base 69 began with pyridine 70, which was converted to Weinreb amide $\mathbf{7 1}$ (Scheme 18). After experimenting with various protecting groups, $p$-methoxybenzyl (PMB) protecting group was used to protect $\mathbf{7 1}$ to yield $\mathbf{7 2}$. Addition of vinyl magnesium bromide to 72 followed by addition of dimethoxy benzyl amine 14 and water gave desired Mannich base $\mathbf{7 4}$.

$\mathrm{A} / \mathrm{B}$ unit $\mathbf{7}$ and Mannich base $\mathbf{7 4}$ were coupled using standard coupling conditions (Scheme 19). It gave desired DARQ 75 in $67 \%$ yield. Removal of DMB group using established conditions gave 77 in 53\% over 2 steps. The final deprotection of the PMB group using a TFA:DCM (1:4) mixture gave desired metabolite 5D in 95\% yield. 
<smiles>[Y20]c1cc(C(=O)N(C)OC)cc(OCc2ccc(OC)cc2)n1</smiles><smiles></smiles>

Scheme 18. Synthesis of intermediate 74. Reagents and conditions: (i) EDCI, HOBT, HNMeOMe.HCl. TEA, $24 \mathrm{~h}, 70 \%$; (ii) $\mathrm{NaH}$, DMF, PMB-Cl, $18 \mathrm{~h}, 32 \%$; (iii) vinylMgBr, THF, $0{ }^{\circ} \mathrm{C}$ then $14, \mathrm{H}_{2} \mathrm{O}, 64 \%$.

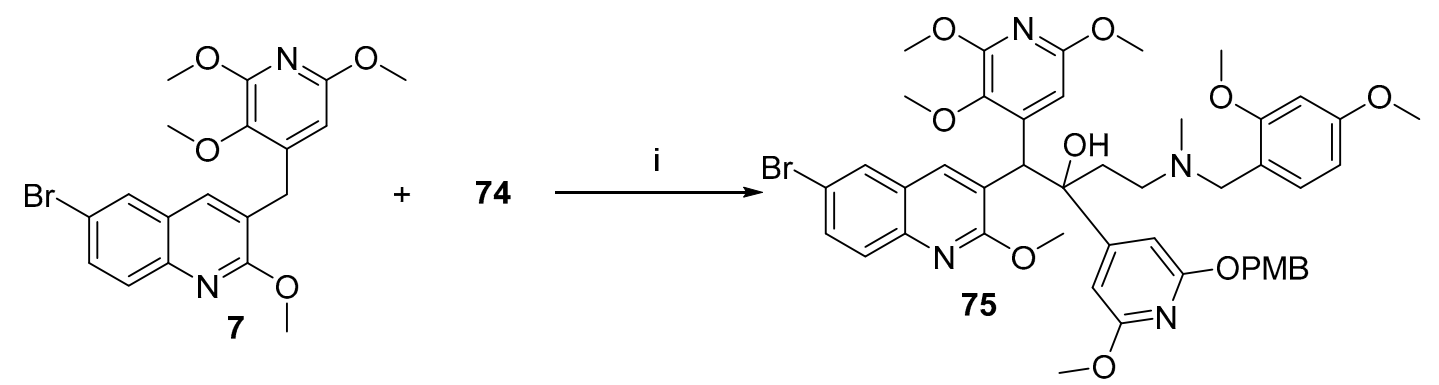

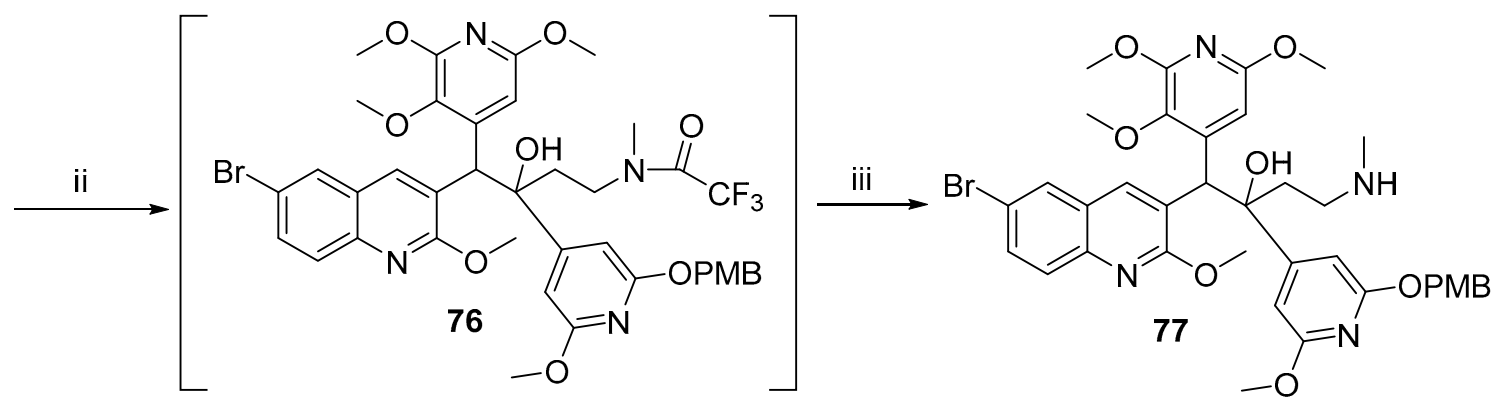<smiles>CNCCC(CO)(Cc1cc(OC)[nH]c(=O)c1)C(c1cc(OC)c2cc(Br)ccc2c1)c1cc(OC)nc(OC)c1OC</smiles>

Scheme 19. Synthesis of metabolite 5D. Reagents and conditions: (i) LDA, THF, $-75^{\circ} \mathrm{C}, 1.5 \mathrm{~h}$ then 55 , $-75^{\circ} \mathrm{C}, 5 \mathrm{~h}, 67 \%$; (ii) TFAA, DCM, $1 \mathrm{~h}$; (iii) $\mathrm{Cs}_{2} \mathrm{CO}_{3}, \mathrm{MeOH},-20{ }^{\circ} \mathrm{C}, 48 \mathrm{~h}, 53 \%$; (iv) TFA:DCM (1:4), $15 \min , 95 \%$. 


\subsubsection{Metabolite 5E}

Metabolite 5E was demethylated on the methoxy group on the quinoline A-ring and mono-demethylated in the dimethylamine D-chain (Scheme 20). Metabolite 5E was synthesized from coupling reaction between $A / B$ unit 78 and Mannich base 15. A/B unit 78 was accessed via Suzuki reaction between boronic acid $\mathbf{7 9}$ and bromide $\mathbf{8 0}$.<smiles>C=CC(=O)Oc1cc(C(O)(CCNC)C(c2cc(OC)nc(OC)c2OC)c2cc3cc(Br)ccc3[nH]c2=O)cc(OC)n1</smiles><smiles>COc1ccc(CN(C)CCC(=O)c2cc(OC)nc(OC)c2)c(Cc2cc3cc(Br)ccc3nc2OC[18O])c1</smiles>

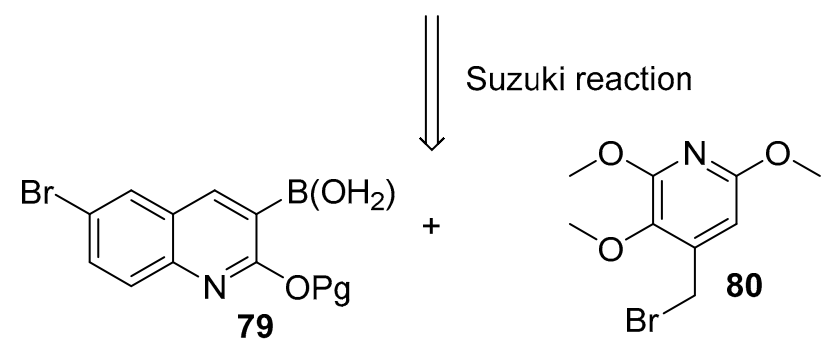

Scheme 20. Proposed synthesis of metabolite 5E.

The synthesis of $\mathrm{A} / \mathrm{B}$ unit $\mathbf{7 8}$ began with boronic acid 31 which was demethylated using $1 \mathrm{M}$ $\mathrm{BBr}_{3}$ solution in DCM (Scheme 21). The reaction was carried out in DMF to give $91 \%$ yield of $\mathbf{8 1}$. DCM and acetonitrile were also screened but only provided low to modest yields of $\mathbf{8 1}$ most likely due to solubility issues. $\mathbf{8 1}$ was protected with EOM group to form $\mathbf{8 2}$ in $69 \%$ yield. The Suzuki reaction between 82 and bromide 80 [14] proceeded well to yield A/B unit 83 in 71\% yield. The coupling reaction between 83 and Mannich base 15 was successful which gave DARQ 84. Deprotection of the DMB group was achieved using standard conditions to yield 86 in 63\% over 2 steps. 
<smiles>CCOCOc1nc2ccc(Br)cc2cc1B(O)O</smiles><smiles>COc1cc(CBr)c(OC)nc1OC</smiles><smiles>CCOCOc1nc2ccc(Br)cc2cc1Cc1cc(OC)nc(OC)c1OC</smiles>

15<smiles>C=[V]</smiles>

83<smiles>CCOCOc1nc2ccc(Br)cc2cc1C(c1cc(OC)nc(OC)c1OC)C(O)(CCN(C)Cc1ccc(OC)cc1OC)c1cc(OC)nc(OC)c1</smiles>

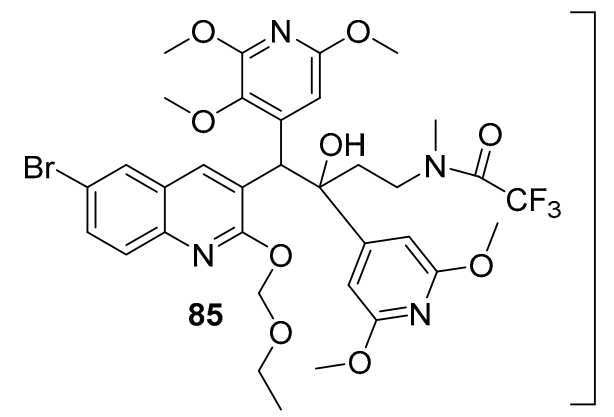<smiles>CCOCOc1nc2ccc(Br)cc2cc1C(c1cc(OC)nc(OC)c1OC)C(O)(CCNC)c1cc(OC)nc(OC)c1</smiles><smiles>CNCCC(O)(c1cc(OC)nc(OC)c1)C(c1cc(OC)nc(OC)c1OC)c1cc2cc(Br)ccc2[nH]c1=O</smiles>

Scheme 21. Synthesis of key intermediates 83 and 86. Reagents and conditions: (i) $1 \mathrm{M} \mathrm{BBr}_{3}$ in $\mathrm{DCM}$,

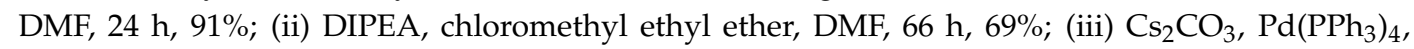
$\mathrm{PhMe} / \mathrm{DMF}, 50{ }^{\circ} \mathrm{C}$ (sealed tube), $2.5 \mathrm{~h}, 71 \%$; (iv) LDA, THF, $-75^{\circ} \mathrm{C}, 1.5 \mathrm{~h}$ then $15,-75{ }^{\circ} \mathrm{C}, 5 \mathrm{~h}, 53 \%$; (v) TFAA, DCM, 1 h; (vi) $\mathrm{Cs}_{2} \mathrm{CO}_{3}, \mathrm{MeOH},-20^{\circ} \mathrm{C}, 96 \mathrm{~h}, 63 \%$.

The removal of the EOM protecting group of $\mathbf{8 6}$ was problematic (Scheme 22). EOM group deprotection is normally carried out in acidic conditions (e.g., using $2 \mathrm{M} \mathrm{HCl}$ in diethyl ether at room temperatures). However, the EOM group off substrate 86, was not cleaved even in strong acidic conditions at refluxing temperatures (Table 3, conditions 1,2). Various other conditions were screened (Table 3). Conditions 3-6 led either to decomposition or gave back unreacted starting materials. When a $1 \mathrm{M} \mathrm{BBr}_{3}$ solution in $\mathrm{DCM}$ was used (conditions 7,8 ), it was possible to remove the EOM protecting group to yield metabolite $5 \mathrm{E}$. However, it also generated byproducts 87 and 88 in which a methoxy group was also removed. After the careful optimisation of the reaction temperature and the equivalence of $\mathrm{BBr}_{3}$, reaction mixture containing higher ratio of the desired product $5 \mathrm{E}$ along with demethylated byproducts 87 and 88 could be obtained (condition 8 ). The mixture products $5 \mathrm{E}, 87$ and 88 were separated into pure fractions using preparative supercritical fluid chromatography to give a pure batch of metabolite $5 \mathrm{E}$. 


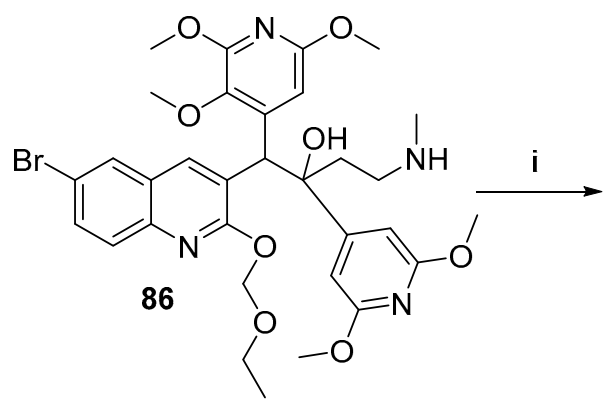

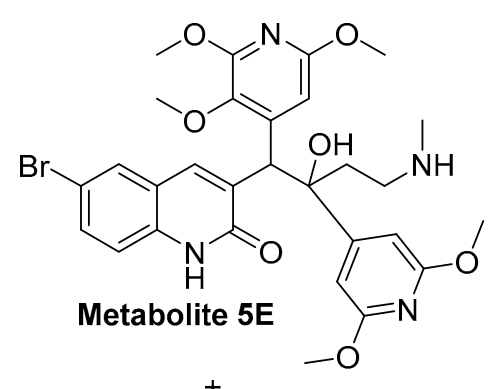<smiles>CNCCC(O)(c1cc(OC)nc(OC)c1OC)C(c1cc(OC)nc(OC)c1OC)c1cc2cc(Br)ccc2[nH]c1=O</smiles><smiles>CCOCOc1nc2ccc(Br)cc2cc1C(c1cc(OC)nc(OC)c1OC)C(O)(CCNC)c1cc(OC)nc(OC)c1</smiles>

Scheme 22. Synthesis of metabolite $5 \mathrm{E}$. Reagents and conditions: (i) $1 \mathrm{M} \mathrm{BBr} 3$ in $\mathrm{DCM}, \mathrm{DCM},-75^{\circ} \mathrm{C}$, $3 \mathrm{~h}$ then $-20{ }^{\circ} \mathrm{C}, 72 \mathrm{~h}, 14 \%$.

Table 3. Summary of conditions explored for removal of EM protecting group from 86.

\begin{tabular}{|c|c|c|c|c|c|}
\hline & Reagents & Solvent & Temp & Time & Products (\% Yield) \\
\hline 1 & 2M HCl diethyl ether & DCM & $150^{\circ} \mathrm{C}$ & $24 \mathrm{~h}$ & - \\
\hline 2 & 4M HCl diethyl ether & benzene & $150^{\circ} \mathrm{C}$ & $24 \mathrm{~h}$ & - \\
\hline 3 & TFA & DCM & $110^{\circ} \mathrm{C}$ & $24 \mathrm{~h}$ & - \\
\hline 4 & $\begin{array}{c}\text { Pyridinium } \\
p \text {-toluenesulfonate }\end{array}$ & butanol & $110^{\circ} \mathrm{C}$ & $24 \mathrm{~h}$ & Trace of $5 \mathrm{E}$ \\
\hline 5 & $\begin{array}{l}\text { Tetra- } n \text {-butylammonium } \\
\text { bromide, TMS-Cl }\end{array}$ & DCM & $110^{\circ} \mathrm{C}$ & $24 \mathrm{~h}$ & - \\
\hline 6 & $\mathrm{CBr}_{4}$ & $i-\mathrm{PrOH}$ & $110^{\circ} \mathrm{C}$ & $24 \mathrm{~h}$ & - \\
\hline 7 & $1 \mathrm{M} \mathrm{BBr}_{3}$ (5 eq.) & DCM & $0{ }^{\circ} \mathrm{C}$ & $24 \mathrm{~h}$ & $\begin{array}{c}\text { 5E:87:88 } \\
(\sim 10 \%: 8 \%: 9 \%)\end{array}$ \\
\hline 8 & $1 \mathrm{M} \mathrm{BBr}_{3}$ (3 eq.) & DCM & $\begin{array}{c}-78{ }^{\circ} \mathrm{C} \text { then } \\
-20{ }^{\circ} \mathrm{C}\end{array}$ & $3 \mathrm{~h}$ then $72 \mathrm{~h}$ & $\begin{array}{c}\text { 5E:87:88 } \\
(\sim 14 \%: 5 \%: 10 \%)\end{array}$ \\
\hline
\end{tabular}

\section{Materials and Methods}

\section{General}

Melting points were determined on an Electrothermal 2300 melting point apparatus. NMR spectra were obtained on a Bruker Avance 400 spectrometer at $400 \mathrm{MHz}$ for ${ }^{1} \mathrm{H}$ and $100 \mathrm{MHz}$ for ${ }^{13} \mathrm{C}$ spectra and are referenced to $\mathrm{Me}_{4} \mathrm{Si}$. Chemical shifts and coupling constants are recorded in units of ppm and $\mathrm{Hz}$, respectively. Low resolution atmospheric pressure chemical ionization mass spectra $([\mathrm{M}+\mathrm{H}])$ of intermediates were measured for methanol solutions on a ThermoFinnigan Surveyor MSQ mass spectrometer. Thin-layer chromatography was carried out on aluminium-backed silica gel plates (Merck $60 \mathrm{~F}_{254}$ ) with visualization of components by UV light $\left(254 \mathrm{~nm}\right.$ ) and/or exposure to $\mathrm{I}_{2}$. Column chromatography was carried out on silica gel (Merck 230-400 mesh) unless stated otherwise. Alumina for column chromatography was Merck aluminium oxide 90 (standardised). Analysis of the final test compounds was carried out on an Agilent 1200-6110 LCMS system, using the following conditions; 
Column: Sunfrie C-18, $4.6 \times 50$ mm; Mobile phase: ACN (0.05\%TFA)-water (0.05\%TFA); Gradient: $5 \% \mathrm{ACN}$ to $95 \% \mathrm{ACN}$ in $1.0 \mathrm{~min}$, hold $1.0 \mathrm{~min}$, total $2.5 \mathrm{~min}$; flow rate: $1.8 \mathrm{~mL} / \mathrm{min}$; LC detector: UV $214 \mathrm{~nm}, 254 \mathrm{~nm}$; MS ([M + H]): atmospheric pressure electrospray ionisation; MS cone voltage: (V) Positive 4000, Negative 3000. All test compounds were determined to have $>95 \%$ purity.

(6-Bromo-2-methoxyquinolin-3-yl)boronic acid (28). A solution of 2,2,6,6-tetramethylpiperidine (14.4 mL, $84.8 \mathrm{mmol})$ in THF $(100 \mathrm{~mL}$, dist. $\mathrm{Na})$ at $-78{ }^{\circ} \mathrm{C}$ was treated with $n$-BuLi $(33 \mathrm{~mL}, 2.5 \mathrm{M}$ in hexanes, $82.5 \mathrm{mmol}$ ), the solution was then warmed to $-20^{\circ} \mathrm{C}$ for $20 \mathrm{~min}$ and then cooled to $-78^{\circ} \mathrm{C}$. A solution of 6-bromo-2-methoxyquinoline $(10.0 \mathrm{~g}, 42.0 \mathrm{mmol})$ and triisopropylborate $(20.0 \mathrm{~mL}, 87.2 \mathrm{mmol}) \mathrm{in}$ THF (100 mL, dist. Na) was added dropwise and the orange solution was stirred for $3 \mathrm{~h}$ at $-78{ }^{\circ} \mathrm{C}$, warmed to $-40^{\circ} \mathrm{C}$ and then quenched with sat. aq. $\mathrm{NH}_{4} \mathrm{Cl}(500 \mathrm{~mL})$. The mixture was diluted with water $(1 \mathrm{~L})$ and the white precipitate was filtered, triturated with hexanes and dried to give 28 (11.17 g, 94\%) as a white solid [22]. ${ }^{1} \mathrm{H}$ NMR $\left(\mathrm{DMSO}_{\mathrm{d}}\right) \delta 8.44(\mathrm{~s}, 1 \mathrm{H}), 8.15-8.18(\mathrm{~m}, 3 \mathrm{H}), 7.76(\mathrm{dd}, \mathrm{J}=8.8$, $2.3 \mathrm{~Hz}, 1 \mathrm{H}), 7.68(\mathrm{~d}, J=8.9 \mathrm{~Hz}, 1 \mathrm{H}), 3.99$ (s, 3H). LRMS: calculated for $\mathrm{C}_{10} \mathrm{H}_{9} \mathrm{BBrNO}_{3}$ : 281.0; found: $\left[\mathrm{M}+\mathrm{H}-\mathrm{OH}+\mathrm{OCH}_{3}\right]=296.2$.

N,2,6-Trimethoxy-N-methylisonicotinamide (11). Oxalyl chloride (1.34 mL, $15.8 \mathrm{mmol})$ was added to a suspension of 2,6-dimethoxyisonicotinic acid (2.41 g, $13.2 \mathrm{mmol})$ in DCM (70 mL) and DMF (0.20 mL, $2.6 \mathrm{mmol}$ ) at r.t.. The mixture was stirred for $1 \mathrm{~h}$ to give a colourless solution which was cooled to $0{ }^{\circ} \mathrm{C}$. $\mathrm{N}, \mathrm{O}$-dimethylhydroxylamine hydrochloride $(1.42 \mathrm{~g}, 14.6 \mathrm{mmol})$ and pyridine $(3.51 \mathrm{~mL}, 28.9 \mathrm{mmol})$ were added sequentially and the mixture was stirred at r.t. for $18 \mathrm{~h}$, then partitioned between EtOAc and sat. aq. $\mathrm{NaHCO}_{3}$. Column chromatography with hexanes:EtOAc (2:1) gave 11 as a light yellow oil (2.49 g, 83\%) [22]. ${ }^{1} \mathrm{H} \mathrm{NMR}\left(\mathrm{CDCl}_{3}\right) \delta 6.47$ (s, 2H), 3.93 (s, 6H), 3.58 (br s, 3H), 3.32 (s, 3H). LRMS: calculated for $\mathrm{C}_{10} \mathrm{H}_{14} \mathrm{~N}_{2} \mathrm{O}_{4}: 226.1$; found: $[\mathrm{M}+\mathrm{H}]=227.2$.

3-((2,4-Dimethoxybenzyl)(methyl)amino)-1-(2,6-dimethoxypyridin-4-yl)propan-1-one (15). Vinylmagnesium bromide $(17.7 \mathrm{~mL}$ of a $1 \mathrm{~N}$ solution in THF, $17.7 \mathrm{mmol})$ was added to a solution of 11 (2.00 g, $8.84 \mathrm{mmol})$ in dry THF $(30 \mathrm{~mL})$ at $0^{\circ} \mathrm{C}$. The brown solution was warmed to r.t. for $1 \mathrm{~h}$ then a solution of $\mathrm{N}$-methyl-2,4-dimethoxybenzylamine $(4.00 \mathrm{~g}, 22.0 \mathrm{mmol})$ in THF $(10 \mathrm{~mL})$, and water (10 $\mathrm{mL}$ ) was added. The solution was stirred at r.t. for $1 \mathrm{~h}$, then partitioned between EtOAc and water. The solution was dried and evaporated to give a brown oil, which was chromatographed. Elution with EtOAc/hexanes gave fore fractions, then elution with EtOAc gave $15(2.27 \mathrm{~g}, 68 \%)$ as a light yellow oil [22]. ${ }^{1} \mathrm{H} \mathrm{NMR}\left(\mathrm{CDCl}_{3}\right) \delta 7.13(\mathrm{~d}, J=8.9 \mathrm{~Hz}, 1 \mathrm{H}), 6.73(\mathrm{~s}, 2 \mathrm{H}), 6.44-6.41(\mathrm{~m}, 2 \mathrm{H}), 3.59(\mathrm{~s}, 6 \mathrm{H}), 3.88$ $(\mathrm{s}, 3 \mathrm{H}), 3.53(\mathrm{~s}, 3 \mathrm{H}), 3.50(\mathrm{~s}, 2 \mathrm{H}), 3.12(\mathrm{t}, J=7.0 \mathrm{~Hz}, 1 \mathrm{H}), 2.84(\mathrm{t}, J=7.0 \mathrm{~Hz}, 2 \mathrm{H}), 2.26(\mathrm{~s}, 3 \mathrm{H})$. LRMS: calculated for $\mathrm{C}_{20} \mathrm{H}_{26} \mathrm{~N}_{2} \mathrm{O}_{5}: 374.2$; found: $[\mathrm{M}+\mathrm{H}]=375.3$.

General Coupling Procedure. $n$-BuLi (0.91 mL of a $2 \mathrm{~N}$ solution in cyclohexane, $1.81 \mathrm{mmol})$ was added at $-30{ }^{\circ} \mathrm{C}$ under dry nitrogen to a solution of dry diisopropylamine $(0.25 \mathrm{~mL}, 1.81 \mathrm{mmol})$ in dry THF $(6 \mathrm{~mL})$ and the solution was stirred at this temperature for $10 \mathrm{~min}$, then cooled to $-78^{\circ} \mathrm{C}$. A solution of $7(0.63 \mathrm{~g}, 1.51 \mathrm{mmol})$ in dry THF $(6 \mathrm{~mL})$ was added dropwise and the mixture was stirred at $-78{ }^{\circ} \mathrm{C}$ for $90 \mathrm{~min}$, to give a dark, wine-red colored solution. A solution of $15(0.56 \mathrm{~g}, 1.51 \mathrm{mmol}) \mathrm{in}$ dry THF $(7 \mathrm{~mL})$ was added and the reaction mixture was stirred at this temperature for $5 \mathrm{~h}$. Water $(100 \mathrm{~mL})$ was added and the mixture was extracted with EtOAc $(2 \mathrm{x})$. The combined organic extract was washed with sat. aq. $\mathrm{NaHCO}_{3}$ solution, and brine, then dried $\left(\mathrm{Na}_{2} \mathrm{SO}_{4}\right)$ and the solvent removed under reduced pressure. The residue was purified by flash column chromatography.

1-(6-Bromo-2-methoxyquinolin-3-yl)-4-((2,4-dimethoxybenzyl)(methyl)amino)-2-(2,6-dimethoxypyridin-4-yl)-1(2,3,6-trimethoxypyridin-4-yl)butan-2-ol (16). The product was prepared from 7 and 15 using the General Coupling Procedure above. Column chromatography with EtOAc:hexanes (1:1) gave fore fractions, then $\mathbf{1 5}$ as a mixture of isomers (75\%), as a yellow foam which were used crude for the next step. LRMS: calculated for $\mathrm{C}_{39} \mathrm{H}_{45} \mathrm{BrN}_{4} \mathrm{O}_{9}$ : 792.2; found: $[\mathrm{M}+\mathrm{H}]=793.2$.

1-(6-Bromo-2-methoxyquinolin-3-yl)-2-(2,6-dimethoxypyridin-4-yl)-4-(methylamino)-1-(2,3,6-trimethoxypyridin4-yl)butan-2-ol (3). To a solution of $16(1.38 \mathrm{~g}, 1.87 \mathrm{mmol})$ in DCM $(10 \mathrm{~mL})$ cooled to $0{ }^{\circ} \mathrm{C}$, was added 
triethylamine $(0.57 \mathrm{~mL}, 4.11 \mathrm{mmol})$ and trifluoroacetic anhydride $(0.52 \mathrm{~mL}, 3.73 \mathrm{mmol})$. The reaction mixture was stirred for $1 \mathrm{~h}$, poured onto sat. aq. $\mathrm{NaHCO}_{3}(50 \mathrm{~mL})$, extracted with DCM $(3 \times 10 \mathrm{~mL})$. The combined organic layers were dried over $\mathrm{Na}_{2} \mathrm{SO}_{4}$, filtered and concentrated under reduced pressure to obtain a yellowish residue. The crude material was dissolved in $\mathrm{MeOH}(100 \mathrm{~mL})$ and cooled to $-78{ }^{\circ} \mathrm{C}$. Cesium carbonate $(1.82 \mathrm{~g}, 5.59 \mathrm{mmol})$ was added and the reaction mixture was stirred at $-20^{\circ} \mathrm{C}$ for $45 \mathrm{~h}$. Reaction mixture was added water $(100 \mathrm{~mL})$ and extracted with EtOAc $(3 \times 50 \mathrm{~mL})$. The combined organic layers washed with brine $(100 \mathrm{~mL})$, dried over $\mathrm{Na}_{2} \mathrm{SO}_{4}$, filtered and concentrated under reduced pressure to obtain a yellow residue. Column chromatography with DCM/MeOH (9:1) gave $3^{*}$ as a foamy solid $(0.74 \mathrm{~g}, 63 \%) .{ }^{1} \mathrm{H} \mathrm{NMR}\left(\mathrm{CDCl}_{3}, 400 \mathrm{MHz}\right) \delta 8.73(\mathrm{~s}, 1 \mathrm{H})$, $8.12(\mathrm{~s}, 1 \mathrm{H}), 7.83(\mathrm{dd}, J=4.7,2.2 \mathrm{~Hz}, 1 \mathrm{H}), 7.68(\mathrm{~d}, J=8.9 \mathrm{~Hz}, 1 \mathrm{H}), 7.60(\mathrm{dd}, J=8.9,2.2 \mathrm{~Hz}, 1 \mathrm{H}), 7.54-7.51$ $(\mathrm{m}, 2 \mathrm{H}), 7.22(\mathrm{~s}, 1 \mathrm{H}), 6.55(\mathrm{br} \mathrm{s}, 3 \mathrm{H}), 6.49(\mathrm{~s}, 2 \mathrm{H}), 5.49(\mathrm{~s}, 1 \mathrm{H}), 5.38(\mathrm{~s}, 1 \mathrm{H}), 4.21(\mathrm{~s}, 3 \mathrm{H}), 4.01(\mathrm{~s}, 3 \mathrm{H}), 3.93$ $(\mathrm{s}, 3 \mathrm{H}), 3.87(\mathrm{~s}, 9 \mathrm{H}), 3.82(\mathrm{~s}, 9 \mathrm{H}), 3.81(\mathrm{~s}, 3 \mathrm{H}), 3.80(\mathrm{~s}, 3 \mathrm{H}), 2.63-2.51(\mathrm{~m}, 2 \mathrm{H}), 2.32-2.23(\mathrm{~m}, 2 \mathrm{H}), 2.21$ $(\mathrm{s}, 3 \mathrm{H}), 2.13(\mathrm{~s}, 3 \mathrm{H}), 1.88-1.75(\mathrm{~m}, 2 \mathrm{H}), 1.64-1.53(\mathrm{~m}, 2 \mathrm{H})$. (no OH, NH observed). Found: $[\mathrm{M}+\mathrm{H}]^{+}$ = 643.2. HRMS: calculated for $\mathrm{C}_{30} \mathrm{H}_{35} \mathrm{BrN}_{4} \mathrm{O}_{7}$ : 642.1689; found: 642.1701 .

1-(2,6-Dimethoxypyridin-4-yl)-3-(dimethylamino)propan-1-one (24). Vinylmagnesium bromide (32 $\mathrm{mL}$ of a $1 \mathrm{~N}$ solution in THF, $32 \mathrm{mmol})$ was added to a solution of $\mathbf{1 1}(2.45 \mathrm{~g}, 10.8 \mathrm{mmol})$ in dry THF $(100 \mathrm{~mL})$ at $0{ }^{\circ} \mathrm{C}$. The brown solution was warmed to r.t. for $1 \mathrm{~h}$ then dimethylamine $(32 \mathrm{~mL}$ of a $2 \mathrm{~N}$ solution in $\mathrm{THF}, 64 \mathrm{mmol})$ and water $(30 \mathrm{~mL})$ were added. The solution was stirred at r.t. for $1 \mathrm{~h}$, then partitioned between EtOAc and water. The solution was dried and evaporated and column chromatography with DCM:MeOH (95:5) eluted impurities while DCM:MeOH (9:1) gave 24 as an oil (0.81 g, 31\%) [22]. ${ }^{1} \mathrm{H} \mathrm{NMR}\left(\mathrm{CDCl}_{3}\right) \delta 6.74(\mathrm{~s}, 2 \mathrm{H}), 3.95(\mathrm{~s}, 6 \mathrm{H}), 3.06(\mathrm{t}, J=7.0 \mathrm{~Hz}, 2 \mathrm{H}), 2.72(\mathrm{t}, J=7.0 \mathrm{~Hz}, 2 \mathrm{H}), 2.27(\mathrm{~s}, 6 \mathrm{H})$. LRMS: calculated for $\mathrm{C}_{12} \mathrm{H}_{18} \mathrm{~N}_{2} \mathrm{O}_{3}$ : 238.1; found: $[\mathrm{M}+\mathrm{H}]=239.1$.

1-(2,6-Dimethoxypyridin-4-yl)prop-2-en-1-one (12). To a solution of 24 (3.00 g, $11.0 \mathrm{mmol})$ in DCM (50 mL) was added iodomethane $(15.5 \mathrm{~g}, 109.0 \mathrm{mmol})$. The reaction mixture was stirred at r.t. for $14 \mathrm{~h}$. Reaction mixture was washed with water $(3 \times 50 \mathrm{~mL})$. The organic layer was collected and washed with brine $(100 \mathrm{~mL})$, dried over $\mathrm{Na}_{2} \mathrm{SO}_{4}$, filtered and concentrated under reduced pressure to obtain a yellow residue. Column chromatography with hexanes:EtOAc (2:1) gave 12 as an oil $(0.87 \mathrm{~g}, 41 \%) .{ }^{1} \mathrm{H}$ NMR $\left(\mathrm{CDCl}_{3}\right) \delta 7.26(\mathrm{~s}, 1 \mathrm{H}), 6.96(\mathrm{dd}, J=17.2,10.6 \mathrm{~Hz}, 1 \mathrm{H}), 6.43(\mathrm{dd}, J=13.3,1.4 \mathrm{~Hz}, 1 \mathrm{H}), 6.00(\mathrm{dd}, J=10.6$, $1.4 \mathrm{~Hz}, 1 \mathrm{H}), 3.96(\mathrm{~s}, 6 \mathrm{H})$. Found: $[\mathrm{M}+\mathrm{H}]=194.1$. HRMS: calculated for $\mathrm{C}_{10} \mathrm{H}_{11} \mathrm{NO}_{3}$ : 193.0739; found: 193.0730.

1-(2,6-Dimethoxypyridin-4-yl)-3-((diphenylmethylene)amino)propan-1-one (21). To a solution of $\mathbf{1 2}$ (0.87 g, $4.45 \mathrm{mmol})$ in THF $(10 \mathrm{~mL})$, benzophenone imine $(2.42 \mathrm{~g}, 13.4 \mathrm{mmol})$ was added. The reaction mixture was stirred at r.t. for $0.5 \mathrm{~h}$. Water $(50 \mathrm{~mL})$ was then added to the reaction mixture and extracted with EtOAc $(3 \times 50 \mathrm{~mL})$. The combined organic fractions were dried over $\mathrm{Na}_{2} \mathrm{SO}_{4}$, filtered and concentrated under reduced pressure to obtain a yellow residue. Column chromatography with hexanes:EtOAc $(9: 1)$ gave 21 as an oil $(1.13 \mathrm{~g}, 68 \%) .{ }^{1} \mathrm{H}$ NMR $\left(\mathrm{CDCl}_{3}\right) \delta 7.60-7.15(\mathrm{~m}, 10 \mathrm{H}), 6.75(\mathrm{~s}, 2 \mathrm{H}), 3.94(\mathrm{~s}, 6 \mathrm{H}), 3.76$ $(\mathrm{t}, J=6.8 \mathrm{~Hz}, 2 \mathrm{H}), 3.29(\mathrm{t}, J=6.8 \mathrm{~Hz}, 2 \mathrm{H})$. Found: $[\mathrm{M}+\mathrm{H}]=375.2$. HRMS: calculated for $\mathrm{C}_{23} \mathrm{H}_{22} \mathrm{~N}_{2} \mathrm{O}_{3}$ : 374.1630; found: 374.1638 .

1-(6-Bromo-2-methoxyquinolin-3-yl)-2-(2,6-dimethoxypyridin-4-yl)-4-((diphenylmethylene)amino)-1-(2,3,6trimethoxypyridin-4-yl)butan-2-ol (26). The product was prepared from 7 and $\mathbf{2 1}$ using the General Coupling Procedure above. Column chromatography with EtOAc:hexanes (9:1) gave fore fractions, then 26 as a mixture of isomers (35\%), as a yellow foam. ${ }^{1} \mathrm{H} \mathrm{NMR}\left(\mathrm{CDCl}_{3}, 400 \mathrm{MHz}\right) \delta 8.85(\mathrm{~s}, 1 \mathrm{H}), 8.22$ (s, 1H), 7.92-7.87 (m, 2H), 7.69-7.30 (m, 21H), 7.18-7.06 (m, 2H), 6.96-6.87 (m, 4H), 6.65-6.42 (m, 3H), $5.56(\mathrm{~s}, 1 \mathrm{H}), 5.44(\mathrm{~s}, 1 \mathrm{H}), 4.18(\mathrm{~s}, 3 \mathrm{H}), 4.00(\mathrm{~s}, 3 \mathrm{H}), 3.92(\mathrm{~s}, 3 \mathrm{H}), 3.88(\mathrm{~s}, 3 \mathrm{H}), 3.86(\mathrm{~s}, 6 \mathrm{H}), 3.84(\mathrm{~s}, 3 \mathrm{H}), 3.82$ $(\mathrm{s}, 3 \mathrm{H}), 3.82(\mathrm{~s}, 3 \mathrm{H}), 3.80(\mathrm{~s}, 6 \mathrm{H}), 3.40(\mathrm{~s}, 3 \mathrm{H}), 3.22-3.12(\mathrm{~m}, 2 \mathrm{H}), 3.01-2.40(\mathrm{~m}, 2 \mathrm{H}), 2.11-1.85(\mathrm{~m}, 2 \mathrm{H})$, $1.70-1.40(\mathrm{~m}, 2 \mathrm{H})$. Found: $[\mathrm{M}+\mathrm{H}]=793.2$. HRMS: calculated for $\mathrm{C}_{42} \mathrm{H}_{41} \mathrm{BrN}_{4} \mathrm{O}_{7}$ : 792.2159; found: 792.2160 . 
4-Amino-1-(6-bromo-2-methoxyquinolin-3-yl)-2-(2,6-dimethoxypyridin-4-yl)-1-(2,3,6-trimethoxypyridin-4yl)butan-2-ol (4). To a solution of $29(0.42 \mathrm{~g}, 0.528 \mathrm{mmol})$ in DCM $(10 \mathrm{~mL})$ was added sodium carbonate $(0.40 \mathrm{~g}, 3.75 \mathrm{mmol})$ and hydroxylamine hydrochloride $(0.279 \mathrm{~g}, 4.01 \mathrm{mmol})$ at $0{ }^{\circ} \mathrm{C}$. The reaction mixture was stirred at r.t. for $48 \mathrm{~h}$. The reaction mixture was added water $(50 \mathrm{~mL})$ and extracted with EtOAc $(3 \times 50 \mathrm{~mL})$. The combined organic fractions were dried over $\mathrm{Na}_{2} \mathrm{SO}_{4}$, filtered and concentrated under reduced pressure to obtain a yellow residue. Column chromatography with DCM:MeOH (9:1) gave $4^{*}$ as foamy solid $(0.175 \mathrm{~g}, 53 \%)$ as a mixture of isomers. ${ }^{1} \mathrm{H}$ NMR (DMSO, $\left.400 \mathrm{MHz}\right) \delta 8.81$ $(\mathrm{s}, 1 \mathrm{H}), 8.22-8.16(\mathrm{~m}, 3 \mathrm{H}), 7.72-7.51(\mathrm{~m}, 4 \mathrm{H}), 7.19(\mathrm{~s}, 1 \mathrm{H}), 6.52(\mathrm{~s}, 1 \mathrm{H}), 6.46-6.41(\mathrm{~m}, 4 \mathrm{H}), 5.42(\mathrm{~s}, 1 \mathrm{H})$, $5.31(\mathrm{~s}, 1 \mathrm{H}), 4.17(\mathrm{~s}, 3 \mathrm{H}), 3.93(\mathrm{~s}, 3 \mathrm{H}), 3.86(\mathrm{~s}, 3 \mathrm{H}), 3.82(\mathrm{~s}, 3 \mathrm{H}), 3.81(\mathrm{~s}, 3 \mathrm{H}), 3.75(\mathrm{~s}, 3 \mathrm{H}), 3.74(\mathrm{~s}, 3 \mathrm{H}), 3.73$ $(\mathrm{s}, 3 \mathrm{H}), 3.73(\mathrm{~s}, 9 \mathrm{H}), 3.31(\mathrm{~s}, 3 \mathrm{H}), 2.57-2.45(\mathrm{~m}, 2 \mathrm{H}), 2.26-2.13(\mathrm{~m}, 2 \mathrm{H}), 1.85-1.76(\mathrm{~m}, 2 \mathrm{H}), 1.68-1.40$ $(\mathrm{m}, 2 \mathrm{H})$ (no $\mathrm{OH}, \mathrm{NH}$ observed). Found: $[\mathrm{M}+\mathrm{H}]=629.1$. HRMS: calculated for $\mathrm{C}_{29} \mathrm{H}_{33} \mathrm{BrN}_{4} \mathrm{O}_{7}$ : 628.1533; found: 628.1542 .

(2,6-Dimethoxypyridin-3-yl)boronic acid (30). To a solution of 2,6-dimethoxypyridine (10 g, $71.84 \mathrm{mmol})$ and $N, N$-diisopropylamine $(0.50 \mathrm{~mL}, 3.59 \mathrm{mmol})$ in THF $(200 \mathrm{~mL}$, dist. $\mathrm{Na})$ at $-40{ }^{\circ} \mathrm{C}$ under nitrogen was added $n$-BuLi $(43.10 \mathrm{~mL}, 86.21 \mathrm{mmol})$ dropwise. The resultant solution was stirred at $-40{ }^{\circ} \mathrm{C}$ for $5 \mathrm{~min}$, and then warmed to $0^{\circ} \mathrm{C}$ and stirred at this temperature for a further $3 \mathrm{~h}$. The solution was then again cooled to $-40{ }^{\circ} \mathrm{C}$, and triisopropylborate $(24.87 \mathrm{~mL}, 107.76 \mathrm{mmol})$ was added dropwise, and the mixture stirred at r.t. for another $1 \mathrm{~h}$. Water $(50 \mathrm{~mL})$ was added and the solvent was removed in vacuo. To the residue, $1 \mathrm{M} \mathrm{NaOH}(100 \mathrm{~mL})$ was added and the aqueous layer was washed with EtOAc $(2 \times 100 \mathrm{~mL})$. The aqueous layer was then acidified to $\mathrm{pH} 3$ and a solid precipitated. This solid was filtered and dried to afford the product $30(8.10 \mathrm{~g}, 61 \%)$ [22]. ${ }^{1} \mathrm{H}$ NMR $\left(\mathrm{DMSO}-\mathrm{d}_{6}\right) \delta 7.87(\mathrm{~d}, J=7.9 \mathrm{~Hz}$, $1 \mathrm{H}), 6.36(\mathrm{~d}, J=7.9 \mathrm{~Hz}, 1 \mathrm{H}), 3.90(\mathrm{~s}, 3 \mathrm{H}), 3.87(\mathrm{~s}, 3 \mathrm{H})$. LRMS: calculated for $\mathrm{C}_{7} \mathrm{H}_{10} \mathrm{BNO}_{4}$ : 183.1; found: Found: $[\mathrm{M}+\mathrm{H}]=184.2$.

2,6-Dimethoxypyridin-3-ol (31). To a solution of 30 (8.00 g, $43.49 \mathrm{mmol})$ in THF (150 mL, dist. Na) at $0{ }^{\circ} \mathrm{C}$ was added dropwise $32 \%$ peracetic acid in acetic acid $(21.53 \mathrm{~mL}, 86.98 \mathrm{mmol})$ over $10 \mathrm{~min}$. The resultant solution was stirred at r.t. for $2 \mathrm{~h}$. A $10 \%$ solution of sodium sulfite $(75 \mathrm{~mL})$ was then added and the mixture stirred at r.t. for $0.5 \mathrm{~h}$. The solvent was evaporated and the residue partitioned between EtOAc and water. The aqueous layer was extracted twice and the organic layer dried and evaporated. Column chromatography with 9:1 hexanes/EtOAc afforded the product $31(6.05 \mathrm{~g}, 90 \%)$ as white solid [22]. ${ }^{1} \mathrm{H}$ NMR $\left(\mathrm{CDCl}_{3}\right) \delta 7.12(\mathrm{~d}, J=8.3 \mathrm{~Hz}, 1 \mathrm{H}), 6.21(\mathrm{~d}, J=8.2 \mathrm{~Hz}, 1 \mathrm{H}), 4.90(\mathrm{~s}, 1 \mathrm{H}), 7.00$ $(\mathrm{s}, 3 \mathrm{H}), 3.86$ (s, 3H). LRMS: calculated for $\mathrm{C}_{7} \mathrm{H}_{9} \mathrm{NO}_{3}$ : 155.1; found: $[\mathrm{M}+\mathrm{H}]=156.7$.

3-(Ethoxymethoxy)-2,6-dimethoxypyridine (32). To a solution of 31 (6.45 g, $40.97 \mathrm{mmol})$ in DMF (70 mL, anhydrous) at $0{ }^{\circ} \mathrm{C}$ was added $60 \%$ sodium hydride in mineral oil $(41.97 \mathrm{~g}, 9.16 \mathrm{mmol})$ in portions. The mixture was warmed to r.t. and stirred for $1 \mathrm{~h}$. 1-Chloro-2-methoxyethane $(4.37 \mathrm{~mL}, 47.11 \mathrm{mmol})$ was then added, and the resultant mixture stirred at r.t. for a further $2 \mathrm{~h}$. The reaction was diluted with brine $(100 \mathrm{~mL})$ and extracted with EtOAc three times. The organic layer was washed with brine three times, dried and evaporated. Column chromatography with 19:1 hexanes/EtOAc afforded the product $32(8.14 \mathrm{~g}, 93 \%)$ as an oil [22]. ${ }^{1} \mathrm{H}$ NMR $\left(\mathrm{CDCl}_{3}\right) \delta 7.41-7.33(\mathrm{~m}, 1 \mathrm{H}), 6.26-6.17(\mathrm{~m}, 1 \mathrm{H}), 5.15$ $(\mathrm{d}, J=1.9 \mathrm{~Hz}, 2 \mathrm{H}), 3.98(\mathrm{~d}, J=1.8 \mathrm{~Hz}, 3 \mathrm{H}), 3.87(\mathrm{~d}, J=2.0 \mathrm{~Hz}, 3 \mathrm{H}), 3.77(\mathrm{dq}, J=1.8,7.1 \mathrm{~Hz}, 2 \mathrm{H}), 1.22$ $(\mathrm{dt}, J=2.9,7.0 \mathrm{~Hz}, 3 \mathrm{H})$. LRMS: calculated for $\mathrm{C}_{10} \mathrm{H}_{15} \mathrm{NO}_{4}: 213.1$; found: $[\mathrm{M}+\mathrm{H}]=214.1$.

3-(Ethoxymethoxy)-2,6-dimethoxyisonicotinaldehyde (33). To a solution of 32 (4.00 g, $18.78 \mathrm{mmol})$ and $\mathrm{N}, \mathrm{N}$-diisopropylamine $(0.13 \mathrm{~mL}, 0.94 \mathrm{mmol})$ in THF $(60 \mathrm{~mL}$, dist. $\mathrm{Na})$ at $-40{ }^{\circ} \mathrm{C}$ under nitrogen was added $n$-BuLi $(14.09 \mathrm{~mL}, 28.17 \mathrm{mmol})$ dropwise. The resultant solution was stirred at $-40{ }^{\circ} \mathrm{C}$ for $5 \mathrm{~min}$, and then warmed to $0{ }^{\circ} \mathrm{C}$ and stirred at this temperature for a further $3 \mathrm{~h}$. The solution was then again cooled to $-40^{\circ} \mathrm{C}$, and 1-formylpiperidine $(3.75 \mathrm{~mL}, 33.80 \mathrm{mmol})$ was added dropwise, and the mixture stirred at r.t. for another $1 \mathrm{~h}$. Acetic acid $(7.5 \mathrm{~mL})$ was added and the solvent was removed in vacuo. The resultant mixture was partitioned between EtOAc and water, and the organic fraction dried and evaporated. Column chromatography with 19:1 hexanes/EtOAc afforded the product 33 (2.30 g, 
51\%) [22]. ${ }^{1} \mathrm{H}$ NMR $\left(\mathrm{CDCl}_{3}\right) \delta 10.39(\mathrm{~s}, 1 \mathrm{H}), 6.61(\mathrm{~s}, 1 \mathrm{H}), 6.19(\mathrm{~s}, 2 \mathrm{H}), 4.02(\mathrm{~s}, 3 \mathrm{H}), 3.88(\mathrm{~s}, 3 \mathrm{H}), 3.78$ $(\mathrm{q}, J=10.1 \mathrm{~Hz}, 2 \mathrm{H}), 1.21(\mathrm{t}, J=7.1 \mathrm{~Hz}, 3 \mathrm{H})$. LRMS: calculated for $\mathrm{C}_{11} \mathrm{H}_{15} \mathrm{NO}_{5}: 241.1$; found: $[\mathrm{M}+\mathrm{H}]$ $=242.2$.

(3-(Ethoxymethoxy)-2,6-dimethoxypyridin-4-yl)methanol (34). A mixture of $33(1.20 \mathrm{~g}, 4.98 \mathrm{mmol})$ in $\mathrm{MeOH}$ ( $30 \mathrm{~mL}$, anhydrous) at $0{ }^{\circ} \mathrm{C}$ was added sodium borohydride $(0.38 \mathrm{~g}, 9.96 \mathrm{mmol})$. The reaction mixture was stirred at r.t. for $2 \mathrm{~h}$. The solvent was then removed and the residue partitioned between EtOAc and water. The organic layer was dried and evaporated to afford the product $34(1.12 \mathrm{~g}, 93 \%) .{ }^{1} \mathrm{H}$ NMR $\left(\mathrm{CDCl}_{3}\right) \delta 6.31(\mathrm{~s}, 1 \mathrm{H}), 5.08(\mathrm{~s}, 2 \mathrm{H}), 4.59(\mathrm{~d}, J=6.5 \mathrm{~Hz}, 2 \mathrm{H}), 3.96(\mathrm{~s}, 3 \mathrm{H}), 3.88(\mathrm{~s}, 3 \mathrm{H}), 3.81-3.75(\mathrm{~m}, 2 \mathrm{H})$, $3.03(\mathrm{t}, J=6.6 \mathrm{~Hz}, 1 \mathrm{H}), 1.26-1.22(\mathrm{~m}, 3 \mathrm{H})$. Found: $[\mathrm{M}+\mathrm{H}]=244.2$. HRMS: calculated for $\mathrm{C}_{11} \mathrm{H}_{17} \mathrm{NO}_{5}$ : 243.1107; found: 243.1110 .

4-(Bromomethyl)-3-(ethoxymethoxy)-2,6-dimethoxypyridine (35). To a solution of 34 (1.12 g, $4.61 \mathrm{mmol})$ and triethylamine $(1.03 \mathrm{~mL}, 7.37 \mathrm{mmol})$ in DCM $(20 \mathrm{~mL}$, anhydrous $)$ at r.t., mesyl chloride $(0.43 \mathrm{~mL}$, $5.53 \mathrm{mmol})$ was added dropwise. After $30 \mathrm{~min}$, the reaction was diluted with DCM $(20 \mathrm{~mL})$ and the organic layer washed with sat. aq. $\mathrm{NaHCO}_{3}$, dried and evaporated. The residue was dissolved in acetone ( $40 \mathrm{~mL}$, anhydrous), lithium bromide $(1.20 \mathrm{~g}, 14.0 \mathrm{mmol})$ added, and the mixture heated at reflux for $30 \mathrm{~min}$. The solution was then cooled and the solvent evaporated, and the residue partitioned between EtOAc and water. The aqueous layer was extracted twice with EtOAc and the organic layer was dried and evaporated to give the product $35(1.40 \mathrm{~g}, 99 \%) .{ }^{1} \mathrm{H} \mathrm{NMR}\left(\mathrm{CDCl}_{3}\right) \delta 6.32(\mathrm{~s}, 1 \mathrm{H}), 5.14$ $(\mathrm{s}, 2 \mathrm{H}), 4.45(\mathrm{~s}, 2 \mathrm{H}), 3.95(\mathrm{~s}, 3 \mathrm{H}), 3.87(\mathrm{~s}, 3 \mathrm{H}), 3.83(\mathrm{q}, J=7.1 \mathrm{~Hz}, 2 \mathrm{H}), 1.26(\mathrm{t}, J=7.1 \mathrm{~Hz}, 3 \mathrm{H})$. Found: $[\mathrm{M}+\mathrm{H}]=306.1$. HRMS: calculated for $\mathrm{C}_{11} \mathrm{H}_{16} \mathrm{BrNO}_{4}$ : 305.0263; found: 305.0265 .

6-Bromo-3-((3-(ethoxymethoxy)-2,6-dimethoxypyridin-4-yl)methyl)-2-methoxyquinoline (36). A mixture of $28(1.84 \mathrm{~g}, 6.56 \mathrm{mmol}), 35(2.00 \mathrm{~g}, 6.56 \mathrm{mmol})$ and cesium carbonate $(4.49 \mathrm{~g}, 14.0 \mathrm{mmol})$ in toluene (40 mL, anhydrous) and DMF (20 mL, anhydrous) was purged with nitrogen. $\mathrm{Pd}\left(\mathrm{PPh}_{3}\right)_{4}(0.38 \mathrm{~g}$, $0.33 \mathrm{mmol}$ ) was then added, the mixture purged with nitrogen then heated to $35^{\circ} \mathrm{C}$ under nitrogen for $1 \mathrm{~h}$. The reaction was partitioned between EtOAc and water and the organic fraction was dried and evaporated. Column chromatography $\left(9: 1\right.$ hexanes/EtOAc) gave the product $36(3.01 \mathrm{~g}, 76 \%) .{ }^{1} \mathrm{H}$ $\operatorname{NMR}\left(\mathrm{CDCl}_{3}\right) \delta 7.76(\mathrm{~d}, J=2.2 \mathrm{~Hz}, 1 \mathrm{H}), 7.69(\mathrm{~d}, J=8.9 \mathrm{~Hz}, 1 \mathrm{H}), 7.61(\mathrm{dd}, J=8.9,2.2 \mathrm{~Hz}, 1 \mathrm{H}), 7.53$ $(\mathrm{s}, 1 \mathrm{H}), 6.02(\mathrm{~s}, 1 \mathrm{H}), 5.07(\mathrm{~s}, 2 \mathrm{H}), 4.07(\mathrm{~s}, 3 \mathrm{H}), 4.05(\mathrm{~s}, 2 \mathrm{H}), 3.97(\mathrm{~s}, 3 \mathrm{H}), 3.83(\mathrm{~s}, 3 \mathrm{H}), 3.75(\mathrm{q}, J=7.1 \mathrm{~Hz}$, 2H), $1.18(\mathrm{t}, J=7.1 \mathrm{~Hz}, 3 \mathrm{H}) .{ }^{13} \mathrm{C} \mathrm{NMR}\left(\mathrm{CDCl}_{3}\right) \delta 161.1,158.2,155.4,145.4,144.4,136.3,132.8,132.2$, $129.4,128.7,126.9,125.2,117.3,101.5,97.4,65.7,53.9,53.8,53.7,30.1,15.3$. Found: $[\mathrm{M}+\mathrm{H}]=463.1$. HRMS: calculated for $\mathrm{C}_{21} \mathrm{H}_{23} \mathrm{BrN}_{2} \mathrm{O}_{5}$ : 462.0790; found: 462.0794 .

1-(6-Bromo-2-methoxyquinolin-3-yl)-4-((2,4-dimethoxybenzyl)(methyl)amino)-2-(2,6-dimethoxypyridin-4-yl)1-(3-(ethoxymethoxy)-2,6-dimethoxypyridin-4-yl)butan-2-ol (37). The product was prepared from 36 and 15 using the General Coupling Procedure above. Column chromatography with EtOAc:hexanes (1:1) gave fore fractions, then 37 as a mixture of isomers $(69 \%)$, as a yellow foam which were used crude for the next step. LRMS: calculated for $\mathrm{C}_{41} \mathrm{H}_{49} \mathrm{BrN}_{4} \mathrm{O}_{10}$ : 836.3; found: $[\mathrm{M}+\mathrm{H}]=837.2$.

1-(6-Bromo-2-methoxyquinolin-3-yl)-2-(2,6-dimethoxypyridin-4-yl)-1-(3-(ethoxymethoxy)-2,6-dimethoxypyridin4-yl)-4-(methylamino)butan-2-ol (39). To a solution of 37 (1.87 g, $2.24 \mathrm{mmol})$ in DCM (100 mL) cooled to $0{ }^{\circ} \mathrm{C}$, was added triethylamine $(0.69 \mathrm{~mL}, 4.93 \mathrm{mmol})$ and trifluoroacetic anhydride $(0.62 \mathrm{~mL}, 4.47 \mathrm{mmol})$. The reaction mixture was stirred for $1 \mathrm{~h}$, poured onto sat. aq. $\mathrm{NaHCO}_{3}(150 \mathrm{~mL})$, extracted with $\mathrm{DCM}$ $(3 \times 100 \mathrm{~mL})$. The combined organic layers were dried over $\mathrm{Na}_{2} \mathrm{SO}_{4}$, filtered and concentrated under reduced pressure to obtain a yellowish residue. The crude material was dissolved in $\mathrm{MeOH}(100 \mathrm{~mL})$ and cooled to $-78{ }^{\circ} \mathrm{C}$. Cesium carbonate $(1.82 \mathrm{~g}, 5.60 \mathrm{mmol})$ in water $(3 \mathrm{~mL})$ was added and the reaction mixture was stirred at $-20^{\circ} \mathrm{C}$ for $72 \mathrm{~h}$. Reaction mixture was added water $(150 \mathrm{~mL})$ and extracted with EtOAc $(3 \times 100 \mathrm{~mL})$. The combined organic layers washed with brine $(100 \mathrm{~mL})$, dried over $\mathrm{Na}_{2} \mathrm{SO}_{4}$, filtered and concentrated under reduced pressure to obtain a yellow residue. Column chromatography with DCM:MeOH (9:1) gave $39(0.75 \mathrm{~g}, 49 \%)$ as a mixture of isomers. ${ }^{1} \mathrm{H}$ NMR $\left(\mathrm{CDCl}_{3}, 400 \mathrm{MHz}\right) \delta 8.69(\mathrm{~s}, 1 \mathrm{H}), 8.04(\mathrm{~s}, 1 \mathrm{H}), 7.83-7.80(\mathrm{~m}, 2 \mathrm{H}), 7.68(\mathrm{~d}, \mathrm{~J}=8.8 \mathrm{~Hz}, 1 \mathrm{H}), 7.60(\mathrm{dd}, \mathrm{J}=8.9$, 
$2.2 \mathrm{~Hz}, 1 \mathrm{H}), 7.56-7.49(\mathrm{~m}, 2 \mathrm{H}), 7.28-7.26(\mathrm{~m}, 2 \mathrm{H}), 6.58(\mathrm{~s}, 2 \mathrm{H}), 6.48(\mathrm{~s}, 2 \mathrm{H}), 5.49(\mathrm{~s}, 1 \mathrm{H}), 5.38(\mathrm{~s}, 1 \mathrm{H})$, $5.21(\mathrm{q}, \mathrm{J}=4.6 \mathrm{~Hz}, 2 \mathrm{H}), 4.82-4.73(\mathrm{~m}, 2 \mathrm{H}), 4.18(\mathrm{~s}, 3 \mathrm{H}), 4.01-3.98(\mathrm{~m}, 2 \mathrm{H}), 3.98(\mathrm{~s}, 6 \mathrm{H}), 3.87(\mathrm{~s}, 3 \mathrm{H})$, $3.85(\mathrm{~s}, 3 \mathrm{H}), 3.83(\mathrm{~s}, 3 \mathrm{H}), 3.82(\mathrm{~s}, 3 \mathrm{H}), 3.80(\mathrm{~s}, 6 \mathrm{H}), 3.79(\mathrm{~s}, 3 \mathrm{H}), 3.79-3.73(\mathrm{~m}, 2 \mathrm{H}), 2.65-2.53(\mathrm{~m}, 2 \mathrm{H})$, 2.32-2.22 (m, 2H), $2.22(\mathrm{~s}, 3 \mathrm{H}), 2.12(\mathrm{~s}, 3 \mathrm{H}), 1.92-1.82(\mathrm{~m}, 2 \mathrm{H}), 1.63-1.55(\mathrm{~m}, 2 \mathrm{H}), 1.39(\mathrm{t}, \mathrm{J}=7.1 \mathrm{~Hz}$, $3 \mathrm{H}), 1.23(\mathrm{t}, \mathrm{J}=7.1 \mathrm{~Hz}, 3 \mathrm{H})$ (no $\mathrm{OH}, \mathrm{NH}$ observed). Found: $[\mathrm{M}+\mathrm{H}]=687.2$. HRMS: calculated for $\mathrm{C}_{32} \mathrm{H}_{39} \mathrm{BrN}_{4} \mathrm{O}_{8}$ : 686.1951; found: 686.1955 .

4-(1-(6-Bromo-2-methoxyquinolin-3-yl)-2-(2,6-dimethoxypyridin-4-yl)-2-hydroxy-4-(methylamino)butyl)-2,6dimethoxypyridin-3-ol (5A). To a solution of $39(0.70 \mathrm{~g}, 1.02 \mathrm{mmol})$ in dioxane $(5 \mathrm{~mL})$ was added $1 \mathrm{M} \mathrm{HCl}(5 \mathrm{~mL})$. The reaction mixture was stirred for $24 \mathrm{~h}$, poured onto sat. aq. $\mathrm{NaHCO}_{3}(10 \mathrm{~mL})$, extracted with EtOAc $(3 \times 10 \mathrm{~mL})$. The combined organic layers were dried over $\mathrm{Na}_{2} \mathrm{SO}_{4}$, filtered and concentrated under reduced pressure to obtain a yellowish residue. Column chromatography with EtOAc:MeOH (9:1) gave fore fractions, followed by isomer A of $\mathbf{5 A}^{*}(0.13 \mathrm{~g}, \mathbf{2 0} \%)$. Elution with EtOAc:MeOH (4:1) gave isomer B of 5A* $(0.18 \mathrm{~g}, 27 \%)$. Isomer A: ${ }^{1} \mathrm{H}$ NMR $\left(\mathrm{CDCl}_{3}, 400 \mathrm{MHz}\right) \delta 8.48$ $(\mathrm{s}, 1 \mathrm{H}), 7.90(\mathrm{~d}, J=2.0 \mathrm{~Hz}, 1 \mathrm{H}), 7.68-7.60(\mathrm{~m}, 2 \mathrm{H}), 6.51(\mathrm{~s}, 2 \mathrm{H}), 6.08(\mathrm{~s}, 1 \mathrm{H}), 5.00(\mathrm{~s}, 1 \mathrm{H}), 4.15(\mathrm{~s}, 3 \mathrm{H})$, $3.88(\mathrm{~s}, 9 \mathrm{H}), 3.61(\mathrm{~s}, 3 \mathrm{H}), 2.65-2.60(\mathrm{~m}, 1 \mathrm{H}), 2.40-2.32(\mathrm{~m}, 1 \mathrm{H}), 2.19(\mathrm{~s}, 3 \mathrm{H}), 1.90-1.85(\mathrm{~m}, 1 \mathrm{H}), 1.77-1.69$ $(\mathrm{m}, 1 \mathrm{H})$, (no $\mathrm{OH}, \mathrm{NH}$ observed) Found: $[\mathrm{M}+\mathrm{H}]=629.2$. HRMS: calculated for $\mathrm{C}_{29} \mathrm{H}_{33} \mathrm{BrN}_{4} \mathrm{O}_{7}$ : 628.1533; found: 628.1543. Isomer B: ${ }^{1} \mathrm{H} \mathrm{NMR}\left(\mathrm{CDCl}_{3}, 400 \mathrm{MHz}\right) \delta 8.28(\mathrm{~s}, 1 \mathrm{H}), 7.78(\mathrm{~d}, J=1.9 \mathrm{~Hz}, 1 \mathrm{H})$, 7.58-7.51 (m, 2H), $6.32(\mathrm{~s}, 2 \mathrm{H}), 6.18(\mathrm{~s}, 1 \mathrm{H}), 5.04(\mathrm{~s}, 1 \mathrm{H}), 4.01(\mathrm{~s}, 3 \mathrm{H}), 3.83(\mathrm{~s}, 6 \mathrm{H}), 3.81(\mathrm{~s}, 3 \mathrm{H}), 3.77$ $(\mathrm{s}, 3 \mathrm{H}), 2.95-2.90(\mathrm{~m}, 1 \mathrm{H}), 2.74-2.68(\mathrm{~m}, 1 \mathrm{H}), 2.51(\mathrm{~s}, 3 \mathrm{H}), 2.20-2.02(\mathrm{~m}, 2 \mathrm{H})$ (no OH, NH observed) Found: $[\mathrm{M}+\mathrm{H}]=629.2$. HRMS: calculated for $\mathrm{C}_{29} \mathrm{H}_{33} \mathrm{BrN}_{4} \mathrm{O}_{7}$ : 628.1533; found: 628.1543.

4-((6-Bromo-2-methoxyquinolin-3-yl)methyl)-5,6-dimethoxypyridin-2(1H)-one (41). To a solution of $\mathbf{7}$ (0.60 g, $1.44 \mathrm{mmol})$ in DMF ( $5 \mathrm{~mL})$ was added lithium chloride $(0.30 \mathrm{~g}, 7.18 \mathrm{mmol})$ and $p$-toluenesulfonic acid $(1.24 \mathrm{~g}, 7.18 \mathrm{mmol})$. The reaction mixture was heated at $120^{\circ} \mathrm{C}$ for $1 \mathrm{~h}$. Reaction mixture was washed with water, extracted with EtOAc $(3 \times 20 \mathrm{~mL})$. The organic fractions were collected and washed with brine $(100 \mathrm{~mL})$, dried over $\mathrm{Na}_{2} \mathrm{SO}_{4}$, filtered and concentrated under reduced pressure to obtain a yellow residue. Column chromatography with EtOAc gave 41 (0.52 g, 90\%). ${ }^{1} \mathrm{H}$ NMR (DMSO) $\delta 12.0$ $(\mathrm{s}, 1 \mathrm{H}), 7.89(\mathrm{~d}, J=2.2 \mathrm{~Hz}, 1 \mathrm{H}), 7.58(\mathrm{dd}, J=8.7,2.2 \mathrm{~Hz}, 1 \mathrm{H}), 7.55(\mathrm{~s}, 1 \mathrm{H}), 7.24(\mathrm{~d}, J=8.8 \mathrm{~Hz}, 1 \mathrm{H}), 6.16$ $(\mathrm{s}, 1 \mathrm{H}), 3.91(\mathrm{~s}, 3 \mathrm{H}), 3.78(\mathrm{~s}, 3 \mathrm{H}), 3.76(\mathrm{~s}, 2 \mathrm{H}), 3.64(\mathrm{~s}, 3 \mathrm{H})$. Found: $[\mathrm{M}+\mathrm{H}]=405.1$. HRMS: calculated for $\mathrm{C}_{18} \mathrm{H}_{17} \mathrm{BrN}_{2} \mathrm{O}_{4}$ : 404.0372; found: 404.0374 .

6-Bromo-3-((6-(ethoxymethoxy)-2,3-dimethoxypyridin-4-yl)methyl)-2-methoxyquinoline (43). To a solution of $41(0.52 \mathrm{~g}, 1.29 \mathrm{mmol})$ in DCM $(25 \mathrm{~mL})$ was added diisopropylethylamine $(0.34 \mathrm{~mL}, 1.94 \mathrm{mmol})$ followed by chloromethyl ethyl ether $(0.24 \mathrm{~mL}, 2.58 \mathrm{mmol})$. The mixture was warmed to $50{ }^{\circ} \mathrm{C}$ and stirred for $18 \mathrm{~h}$. The reaction was washed with water $(50 \mathrm{~mL})$ and extracted with EtOAc $(3 \times 50 \mathrm{~mL})$. The organic fractions were collected and washed with brine $(100 \mathrm{~mL})$, dried over $\mathrm{Na}_{2} \mathrm{SO}_{4}$, filtered and concentrated under reduced pressure to obtain a yellow residue. Column chromatography with hexanes:EtOAc (9:1) gave $43(0.30 \mathrm{~g}, 49 \%) .{ }^{1} \mathrm{H}$ NMR $\left(\mathrm{CDCl}_{3}\right) \delta 7.77(\mathrm{~d}, J=2.1 \mathrm{~Hz}, 1 \mathrm{H}), 7.67(\mathrm{~d}, J=8.9 \mathrm{~Hz}, 1 \mathrm{H}), 7.63-7.60$ $(\mathrm{m}, 2 \mathrm{H}), 6.04(\mathrm{~s}, 1 \mathrm{H}), 5.75(\mathrm{~s}, 2 \mathrm{H}), 4.02(\mathrm{~s}, 2 \mathrm{H}), 4.00(\mathrm{~s}, 3 \mathrm{H}), 3.84(\mathrm{~s}, 3 \mathrm{H}), 3.72(\mathrm{~s}, 3 \mathrm{H}), 3.70(\mathrm{q}, J=7.1 \mathrm{~Hz}$, $2 \mathrm{H}), 1.22(\mathrm{t}, J=7.0 \mathrm{~Hz}, 3 \mathrm{H}) .{ }^{13} \mathrm{C} \mathrm{NMR}\left(\mathrm{CDCl}_{3}\right) \delta 159.7,157.8,155.7,144.7,144.2,136.9,135.8,132.4$, 129.3, 129.0, 127.0, 125.2, 117.7, 101.4, 91.2, 65.9, 60.7, 53.8, 53.7, 30.2, 15.4. Found: $[\mathrm{M}+\mathrm{H}]=463.1$. HRMS: calculated for $\mathrm{C}_{21} \mathrm{H}_{23} \mathrm{BrN}_{2} \mathrm{O}_{5}$ : 462.0790; found: 462.0788 .

1-(6-Bromo-2-methoxyquinolin-3-yl)-4-((2,4-dimethoxybenzyl)(methyl)amino)-2-(2,6-dimethoxypyridin-4-yl)-1(6-(ethoxymethoxy)-2,3-dimethoxypyridin-4-yl)butan-2-ol (44). The product was prepared from $\mathbf{4 3}$ and $\mathbf{1 5}$ using the General Coupling Procedure above. Column chromatography with EtOAc:hexanes (1:1) gave fore fractions, then 44 as a mixture of isomers $(83 \%)$, as a yellow foam which were used crude for the next step. LRMS: calculated for $\mathrm{C}_{41} \mathrm{H}_{49} \mathrm{BrN}_{4} \mathrm{O}_{10}$ : 836.3; found: $[\mathrm{M}+\mathrm{H}]=837.2$.

4-(1-(6-Bromo-2-methoxyquinolin-3-yl)-2-(2,6-dimethoxypyridin-4-yl)-2-hydroxy-4-(methylamino)butyl)-5,6dimethoxypyridin-2(1H)-one (5B). To a solution of $44(0.44 \mathrm{~g}, 0.53 \mathrm{mmol})$ in DCM $(50 \mathrm{~mL})$ cooled to $0{ }^{\circ} \mathrm{C}$, was added triethylamine $(0.16 \mathrm{~mL}, 1.16 \mathrm{mmol})$ and trifluoroacetic anhydride $(0.15 \mathrm{~mL}, 1.06 \mathrm{mmol})$. 
The reaction mixture was stirred for $1 \mathrm{~h}$, poured onto sat. aq. $\mathrm{NaHCO}_{3}(150 \mathrm{~mL})$, extracted with $\mathrm{DCM}(3 \times 50 \mathrm{~mL})$. The combined organic layers were dried over $\mathrm{Na}_{2} \mathrm{SO}_{4}$, filtered and concentrated under reduced pressure to obtain a yellowish residue. The crude material was dissolved in $\mathrm{MeOH}$ $(100 \mathrm{~mL})$ and cooled to $-78{ }^{\circ} \mathrm{C}$. Cesium carbonate $(0.52 \mathrm{~g}, 1.58 \mathrm{mmol})$ in water $(3 \mathrm{~mL})$ was added and the reaction mixture was stirred at $-20^{\circ} \mathrm{C}$ for $48 \mathrm{~h}$. Reaction mixture was added water $(150 \mathrm{~mL})$ and extracted with EtOAc $(3 \times 50 \mathrm{~mL})$. The combined organic layers washed with brine $(100 \mathrm{~mL})$, dried over $\mathrm{Na}_{2} \mathrm{SO}_{4}$, filtered and concentrated under reduced pressure to obtain a yellow residue. Column chromatography with EtOAc:MeOH (9:1) gave fore fractions, followed by isomer A of 5B* $(0.064 \mathrm{~g}, 19 \%)$. Elution with EtOAc:MeOH (4:1) gave isomer B of 5B* $(0.069 \mathrm{~g}, 21 \%)$. Isomer A: ${ }^{1} \mathrm{H}$ NMR (DMSO, $\left.400 \mathrm{MHz}\right) \delta 8.34(\mathrm{~s}, 1 \mathrm{H}), 7.95(\mathrm{~d}, \mathrm{~J}=2.2 \mathrm{~Hz}, 1 \mathrm{H}), 7.57(\mathrm{~d}, \mathrm{~J}=8.7 \mathrm{~Hz}, 1 \mathrm{H}), 7.12$ $(\mathrm{d}, \mathrm{J}=8.8 \mathrm{~Hz}, 1 \mathrm{H}), 6.56(\mathrm{~s}, 1 \mathrm{H}), 6.42(\mathrm{~s}, 2 \mathrm{H}), 5.24(\mathrm{~s}, 1 \mathrm{H}), 3.91(\mathrm{~s}, 3 \mathrm{H}), 3.90(\mathrm{~s}, 3 \mathrm{H}), 3.76(\mathrm{~s}, 9 \mathrm{H}), 2.53-2.48$ $(\mathrm{m}, 1 \mathrm{H}), 2.36-2.31(\mathrm{~m}, 1 \mathrm{H}), 2.24(\mathrm{~s}, 3 \mathrm{H}), 2.03-1.70(\mathrm{~m}, 2 \mathrm{H})(\mathrm{no} \mathrm{OH}, \mathrm{NH}$ observed) Found: [M + H] = 629.2. HRMS: calculated for $\mathrm{C}_{29} \mathrm{H}_{33} \mathrm{BrN}_{4} \mathrm{O}_{7}$ : 628.1533; found: 628.1543. Isomer B: ${ }^{1} \mathrm{H} \mathrm{NMR}$ (DMSO, $400 \mathrm{MHz}) \delta 8.01(\mathrm{~d}, \mathrm{~J}=2.2 \mathrm{~Hz}, 1 \mathrm{H}), 7.92-7.85(\mathrm{~m}, 1 \mathrm{H}), 7.59(\mathrm{dd}, \mathrm{J}=8.8,1.9 \mathrm{~Hz}, 1 \mathrm{H}), 7.24(\mathrm{~d}, \mathrm{~J}=8.7 \mathrm{~Hz}$, 1H), 7.10-7.08 (m, 1H), 6.43-6.35 (m, 2H), $5.47(\mathrm{~s}, 1 \mathrm{H}), 3.79(\mathrm{~s}, 6 \mathrm{H}), 3.75(\mathrm{~s}, 3 \mathrm{H}), 3.73(\mathrm{~s}, 3 \mathrm{H}), 3.72(\mathrm{~s}, 3 \mathrm{H})$, 2.38-2.22 (m, 1H), 2.14-2.03 (m, 1H), $2.03(\mathrm{~s}, 3 \mathrm{H}), 1.82-1.66(\mathrm{~m}, 2 \mathrm{H})$ (no OH, NH observed) Found: $[\mathrm{M}+\mathrm{H}]=629.2$. HRMS: calculated for $\mathrm{C}_{29} \mathrm{H}_{33} \mathrm{BrN}_{4} \mathrm{O}_{7}: 628.1533$; found: 628.1543 .

5-(Ethoxymethoxy)-2-methoxypyridine (49). To a solution of 6-pyridin-3-ol (3.20 g, $25.4 \mathrm{mmol}) \mathrm{in} \mathrm{DMF}$ (50 mL, anhydrous) at $0{ }^{\circ} \mathrm{C}$ was added $60 \%$ sodium hydride in mineral oil $(1.23 \mathrm{~g}, 30.5 \mathrm{mmol}) \mathrm{in}$ portions. The mixture was warmed to r.t. and stirred for $1 \mathrm{~h}$. 1-Chloro-2-methoxyethane $(2.73 \mathrm{~mL}$, $25.9 \mathrm{mmol}$ ) was then added, and the resultant mixture stirred at r.t. for a further $4 \mathrm{~h}$. The reaction was diluted with brine $(100 \mathrm{~mL})$ and extracted with EtOAc three times. The organic layer was washed with brine three times, dried and evaporated. Column chromatography with 19:1 hexanes/EtOAc afforded the product $49(4.44 \mathrm{~g}, 95 \%) .{ }^{1} \mathrm{H} \mathrm{NMR}\left(\mathrm{CDCl}_{3}\right) \delta 7.95(\mathrm{~d}, J=3.0 \mathrm{~Hz}, 1 \mathrm{H}), 7.34-7.31(\mathrm{~m}, 1 \mathrm{H})$, $6.66(\mathrm{~d}, J=9.0 \mathrm{~Hz}, 1 \mathrm{H}), 5.13(\mathrm{~s}, 2 \mathrm{H}), 3.88(\mathrm{~s}, 3 \mathrm{H}), 3.72(\mathrm{q}, J=7.1 \mathrm{~Hz}, 2 \mathrm{H}), 1.22(\mathrm{t}, J=7.0 \mathrm{~Hz}, 3 \mathrm{H})$. Found: $[\mathrm{M}+\mathrm{H}]=184.6$. HRMS: calculated for $\mathrm{C}_{9} \mathrm{H}_{13} \mathrm{NO}_{3}$ : 183.0895; found: 183.0899.

5-(Ethoxymethoxy)-2-methoxyisonicotinaldehyde (50). To a solution of 49 (3.64 g, $19.9 \mathrm{mmol})$ and $\mathrm{N}, \mathrm{N}$-diisopropylamine $(0.14 \mathrm{~mL}, 0.1 \mathrm{mmol})$ in THF $(60 \mathrm{~mL}$, dist. $\mathrm{Na})$ at $-40{ }^{\circ} \mathrm{C}$ under nitrogen was added $n$-BuLi $(15.0 \mathrm{~mL}, 30.0 \mathrm{mmol})$ dropwise. The resultant solution was stirred at $-40{ }^{\circ} \mathrm{C}$ for $5 \mathrm{~min}$, and then warmed to $0^{\circ} \mathrm{C}$ and stirred at this temperature for a further $3 \mathrm{~h}$. The solution was then again cooled to $-40{ }^{\circ} \mathrm{C}$, and 1-formylpiperidine $(3.98 \mathrm{~mL}, 36.0 \mathrm{mmol})$ was added dropwise, and the mixture stirred at r.t. for another $1 \mathrm{~h}$. Acetic acid $(8 \mathrm{~mL})$ was added and the solvent was removed in vacuo. The resultant mixture was partitioned between EtOAc and water, and the organic fraction dried and evaporated. Column chromatography with 9:1 hexanes/EtOAc afforded the product 50 (2.74 g, 65\%). ${ }^{1} \mathrm{H} \mathrm{NMR}\left(\mathrm{CDCl}_{3}\right) \delta 10.42(\mathrm{~s}, 1 \mathrm{H}), 8.29(\mathrm{~s}, 1 \mathrm{H}), 7.07$ (s, 1H), $5.30(\mathrm{~s}, 2 \mathrm{H}), 3.92(\mathrm{~s}, 3 \mathrm{H})$, $3.78(\mathrm{q}, J=7.1 \mathrm{~Hz}, 2 \mathrm{H}), 1.23(\mathrm{t}, J=7.1 \mathrm{~Hz}, 3 \mathrm{H})$. Found: $[\mathrm{M}+\mathrm{MeOH}]=244.2$. HRMS: calculated for $\mathrm{C}_{10} \mathrm{H}_{13} \mathrm{NO}_{4}$ : 211.0845; found: 211.0849 .

5-Hydroxy-2-methoxyisonicotinaldehyde (51). A solution of 50 (2.74 g, $13.0 \mathrm{mmol})$ and $3 \mathrm{M}$ hydrochloric acid $(30 \mathrm{~mL})$ in THF ( $40 \mathrm{~mL}$, dist. Na) was heated at $40{ }^{\circ} \mathrm{C}$ for $3 \mathrm{~h}$. The solution was then cooled, diluted with water, and the $\mathrm{pH}$ adjusted to 7 using $\mathrm{NaHCO}_{3}$. The aqueous layer was then extracted with EtOAc three times, and the organic layer dried and evaporated. Column chromatography with 4:1 hexanes/EtOAc afforded the product 51 (1.28 g, 64\%) [23]. ${ }^{1} \mathrm{H} \mathrm{NMR}\left(\mathrm{CDCl}_{3}\right) \delta 9.97(\mathrm{~s}, J=0.4 \mathrm{~Hz}$, $1 \mathrm{H}), 9.46(\mathrm{~s}, 1 \mathrm{H}), 8.08(\mathrm{~s}, 1 \mathrm{H}), 6.93(\mathrm{~d}, J=0.5 \mathrm{~Hz}, 1 \mathrm{H}), 3.94(\mathrm{~s}, 3 \mathrm{H})$. LRMS: calculated for $\mathrm{C}_{7} \mathrm{H}_{7} \mathrm{NO}_{3}$ : 153.0; found: $[\mathrm{M}+\mathrm{H}]=154.2$.

2,5-Dimethoxyisonicotinaldehyde (52). A mixture of 51 (1.28 g, $8.36 \mathrm{mmol})$ and potassium carbonate $(1.73 \mathrm{~g}, 12.5 \mathrm{mmol})$ in DMF $\left(50 \mathrm{~mL}\right.$, anhydrous) was heated at $50{ }^{\circ} \mathrm{C}$ for $10 \mathrm{~min}$. Methyl iodide $(1.42 \mathrm{~g}, 10.0 \mathrm{mmol})$ was then added and the mixture stirred at this temperature for $2 \mathrm{~h}$. The resultant solution was diluted with EtOAc and washed with brine three times. The organic layer was dried and 
evaporated to afford the product $52(1.39 \mathrm{~g}, 99 \%)[23] .{ }^{1} \mathrm{H}$ NMR $\left(\mathrm{CDCl}_{3}\right) \delta 10.43(\mathrm{~s}, 1 \mathrm{H}), 8.01(\mathrm{~s}, 1 \mathrm{H})$, $7.08(\mathrm{~d}, J=0.6 \mathrm{~Hz}, 1 \mathrm{H}), 3.97(\mathrm{~s}, 3 \mathrm{H}), 3.91(\mathrm{~s}, 3 \mathrm{H})$. LRMS: calculated for $\mathrm{C}_{8} \mathrm{H}_{9} \mathrm{NO}_{3}$ : 167.1 ; found: $[\mathrm{M}+\mathrm{H}]$ $=168.2$.

4-(1,3-Dioxolan-2-yl)-2,5-dimethoxypyridine (53). A mixture of 52 (0.20 g, $1.20 \mathrm{mmol})$, pyridinium p-toluenesulfonate and ethylene glycol $(0.37 \mathrm{~g}, 5.99 \mathrm{mmol})$ in toluene $(6 \mathrm{~mL}$, anhydrous $)$ was heated at $120{ }^{\circ} \mathrm{C}$ for $6 \mathrm{~h}$. The resultant solution was diluted with EtOAc and washed with sat. NaHCO3 solution. The organic layer was dried and evaporated. Column chromatography with 9:1 hexanes/EtOAc afforded the product $53(0.22 \mathrm{~g}, 88 \%) .{ }^{1} \mathrm{H} \mathrm{NMR}\left(\mathrm{CDCl}_{3}\right) \delta 7.87(\mathrm{~s}, 1 \mathrm{H}), 6.90(\mathrm{~s}, 1 \mathrm{H}), 6.07(\mathrm{~s}, 1 \mathrm{H}), 4.15-3.89$ $(\mathrm{m}, 4 \mathrm{H}), 3.89(\mathrm{~s}, 3 \mathrm{H}), 3.88(\mathrm{~s}, 3 \mathrm{H})$. Found: $[\mathrm{M}+\mathrm{H}]=212.2$. HRMS: calculated for $\mathrm{C}_{10} \mathrm{H}_{13} \mathrm{NO}_{4}$ : 211.0845; found: 211.0836 .

4-(1,3-Dioxolan-2-yl)-2,5-dimethoxypyridine 1-oxide (54). A mixture of 53 (0.22 g, $1.04 \mathrm{mmol})$ in DCM $\left(8 \mathrm{~mL}\right.$, anhydrous) was added $77 \% \mathrm{~m}-\mathrm{CPBA}(0.47 \mathrm{~g}, 2.08 \mathrm{mmol})$ at $0{ }^{\circ} \mathrm{C}$. The reaction mixture was stirred at r.t. for $17 \mathrm{~h}$. The solvent was removed from the reaction mixture and crude product was purified using silica column chromatography with 9:1 DCM/MeOH afforded the product $54(0.17 \mathrm{~g}$, 70\%). ${ }^{1} \mathrm{H} \mathrm{NMR}\left(\mathrm{CDCl}_{3}\right) \delta 8.02(\mathrm{~s}, 1 \mathrm{H}), 7.09$ (s, 1H), $6.00(\mathrm{~s}, 1 \mathrm{H}), 4.15-4.02(\mathrm{~m}, 4 \mathrm{H}), 4.05$ (s, $\left.3 \mathrm{H}\right), 3.85$ $(\mathrm{s}, 3 \mathrm{H})$. Found: $[\mathrm{M}+\mathrm{H}]=228.2$. HRMS: calculated for $\mathrm{C}_{10} \mathrm{H}_{13} \mathrm{NO}_{5}$ : 227.0794; found: 227.0781 .

4-(1,3-Dioxolan-2-yl)-3,6-dimethoxypyridin-2-yl acetate (55). A mixture of 54 (1.84 g, $8.10 \mathrm{mmol})$ in acetic anhydride $(5 \mathrm{~mL})$ was heated at $150{ }^{\circ} \mathrm{C}$ for $3 \mathrm{~h}$. Acetic anhydride was removed from the reaction mixture in vacuo and crude product was purified using silica column chromatography with 1:1 hexanes/EtOAc afforded the product $55(1.54 \mathrm{~g}, 71 \%) .{ }^{1} \mathrm{H} \mathrm{NMR}\left(\mathrm{CDCl}_{3}\right) \delta 6.81(\mathrm{~s}, 1 \mathrm{H}), 6.05(\mathrm{~s}, 1 \mathrm{H})$, 4.12-4.02 (m, 4H), $3.88(\mathrm{~s}, 3 \mathrm{H}), 3.81(\mathrm{~s}, 3 \mathrm{H}), 2.36(\mathrm{~s}, 3 \mathrm{H})$. Found: $[\mathrm{M}+\mathrm{H}]=270.2$. HRMS: calculated for $\mathrm{C}_{12} \mathrm{H}_{15} \mathrm{NO}_{6}$ : 269.0899; found: 269.0887.

3,6-Dimethoxy-2-oxo-1,2-dihydropyridine-4-carbaldehyde (56). A mixture of 55 (1.43 g, $5.32 \mathrm{mmol})$ in chloroform $(4 \mathrm{~mL})$ was added to TFA $(1 \mathrm{~mL})$ and stirred at r.t. for $2 \mathrm{~h}$. Solvent was removed from the reaction mixture in vacuo to give the product $56(0.83 \mathrm{~g}, 85 \%) .{ }^{1} \mathrm{H} \mathrm{NMR}\left(\mathrm{CDCl}_{3}\right) \delta 10.38(\mathrm{~s}, 1 \mathrm{H}), 9.08$ $(\mathrm{s}, 1 \mathrm{H}), 5.74(\mathrm{~s}, 1 \mathrm{H}), 4.07(\mathrm{~s}, 3 \mathrm{H}), 3.86(\mathrm{~s}, 3 \mathrm{H})$. Found: $[\mathrm{M}+\mathrm{H}]=184.2$. HRMS: calculated for $\mathrm{C}_{8} \mathrm{H}_{9} \mathrm{NO}_{4}$ : 183.0532; found: 183.0521 .

2-(Ethoxymethoxy)-3,6-dimethoxyisonicotinaldehyde (57). To a solution of 56 (0.59 g, $3.22 \mathrm{mmol})$ in DMF $(10 \mathrm{~mL})$ was added to diisopropylethylamine $(1.12 \mathrm{~mL}, 6.44 \mathrm{mmol})$ followed by chloromethyl ethyl ether $(0.914 \mathrm{~g}, 9.67 \mathrm{mmol})$. The mixture was stirred at r.t. for $3 \mathrm{~h}$. The reaction was washed with water $(50 \mathrm{~mL})$ and extracted with EtOAc $(3 \times 50 \mathrm{~mL})$. The organic fractions were collected and washed with brine $(100 \mathrm{~mL})$, dried over $\mathrm{Na}_{2} \mathrm{SO}_{4}$, filtered and concentrated under reduced pressure to obtain a yellow residue. Column chromatography with hexanes:EtOAc (9:1) gave $57(0.54 \mathrm{~g}, 69 \%) .{ }^{1} \mathrm{H} \mathrm{NMR}\left(\mathrm{CDCl}_{3}\right) \delta$ $10.40(\mathrm{~s}, 1 \mathrm{H}), 6.64(\mathrm{~s}, 1 \mathrm{H}), 5.68(\mathrm{~s}, 2 \mathrm{H}), 3.96(\mathrm{~s}, 3 \mathrm{H}), 3.88(\mathrm{~s}, 3 \mathrm{H}), 3.82(\mathrm{q}, J=7.1 \mathrm{~Hz}, 2 \mathrm{H}), 1.27(\mathrm{t}, J=7.1 \mathrm{~Hz}$, $3 \mathrm{H})$. Found: $[\mathrm{M}+\mathrm{H}]=242.2$. HRMS: calculated for $\mathrm{C}_{11} \mathrm{H}_{15} \mathrm{NO}_{5}$ : 241.0950; found: 241.0940 .

(2-(Ethoxymethoxy)-3,6-dimethoxypyridin-4-yl)methanol (63). To a mixture of 57 (0.54 g, $2.22 \mathrm{mmol}) \mathrm{in}$ $\mathrm{MeOH}\left(10 \mathrm{~mL}\right.$, anhydrous) at $0{ }^{\circ} \mathrm{C}$, sodium borohydride was added $(0.168 \mathrm{~g}, 4.45 \mathrm{mmol})$. The reaction mixture was stirred at r.t. for $0.5 \mathrm{~h}$. The solvent was then removed and the residue partitioned between EtOAc and water. The organic layer was dried and evaporated to afford the product $63(0.50 \mathrm{~g}, 92 \%)$. ${ }^{\mathrm{f} 1} \mathrm{H} \mathrm{NMR}\left(\mathrm{CDCl}_{3}\right) \delta 6.36(\mathrm{~s}, 1 \mathrm{H}), 5.65(\mathrm{~s}, 2 \mathrm{H}), 4.68(\mathrm{~s}, 2 \mathrm{H}), 3.85(\mathrm{~s}, 3 \mathrm{H}), 3.83(\mathrm{~s}, 3 \mathrm{H}), 3.80(\mathrm{q}, \mathrm{J}=7.1 \mathrm{~Hz}$, $2 \mathrm{H}), 1.26(\mathrm{t}, J=7.1 \mathrm{~Hz}, 3 \mathrm{H})$. Found: $[\mathrm{M}+\mathrm{H}]=244.2$. HRMS: calculated for $\mathrm{C}_{11} \mathrm{H}_{17} \mathrm{NO}_{5}: 243.1107$; found: 243.1110 .

4-(Bromomethyl)-2-(ethoxymethoxy)-3,6-dimethoxypyridine (64). To a solution of 63 (0.40 g, $1.65 \mathrm{mmol})$ and triethylamine $(0.345 \mathrm{~mL}, 2.47 \mathrm{mmol})$ in DCM $(20 \mathrm{~mL}$, anhydrous $)$ at r.t., mesyl chloride $(0.153 \mathrm{~mL}$, $1.98 \mathrm{mmol}$ ) was added dropwise. After $30 \mathrm{~min}$, the reaction was diluted with DCM $(20 \mathrm{~mL})$ and the organic layer washed with sat. aq. $\mathrm{NaHCO}_{3}$, dried and evaporated. The residue was dissolved in acetone $\left(20 \mathrm{~mL}\right.$, anhydrous) and cooled to $0^{\circ} \mathrm{C}$ and added lithium bromide $(0.16 \mathrm{~g}, 1.82 \mathrm{mmol})$. 
The reaction mixture was stirred at $0{ }^{\circ} \mathrm{C}$ for $3 \mathrm{~h}$. The reaction mixture was partitioned between EtOAc and water. The aqueous layer was extracted twice with EtOAc and the organic layer was dried and evaporated to give the product $64(0.49 \mathrm{~g}, 98 \%) .{ }^{1} \mathrm{H} \mathrm{NMR}\left(\mathrm{CDCl}_{3}\right) \delta 6.33(\mathrm{~s}, 1 \mathrm{H}), 5.64(\mathrm{~s}, 2 \mathrm{H}), 4.40$ $(\mathrm{s}, 2 \mathrm{H}), 3.90(\mathrm{~s}, 3 \mathrm{H}), 3.84(\mathrm{~s}, 3 \mathrm{H}), 3.81(\mathrm{q}, J=7.1 \mathrm{~Hz}, 2 \mathrm{H}), 1.26(\mathrm{t}, J=7.1 \mathrm{~Hz}, 3 \mathrm{H})$. Found: $[\mathrm{M}+\mathrm{H}]=306.1$ HRMS: calculated for $\mathrm{C}_{11} \mathrm{H}_{16} \mathrm{BrNO}_{4}$ : 305.0263; found: 305.0268 .

6-bromo-3-((2-(ethoxymethoxy)-3,6-dimethoxypyridin-4-yl)methyl)-2-methoxyquinoline (65). A mixture of $28(0.56 \mathrm{~g}, 1.97 \mathrm{mmol}), 64(0.50 \mathrm{~g}, 1.65 \mathrm{mmol})$ and cesium carbonate $(1.07 \mathrm{~g}, 3.30 \mathrm{mmol})$ in toluene (20 mL, anhydrous) and DMF $\left(10 \mathrm{~mL}\right.$, anhydrous) was purged with nitrogen. $\mathrm{Pd}\left(\mathrm{PPh}_{3}\right)_{4}(0.095 \mathrm{~g}, 0.083$ mmol) was then added, the mixture purged with nitrogen then heated to $50{ }^{\circ} \mathrm{C}$ under nitrogen for $0.5 \mathrm{~h}$. The reaction was partitioned between EtOAc and water and the organic fraction was dried and evaporated. Column chromatography (9:1 hexanes/EtOAc) gave the product $65(0.77 \mathrm{~g}, 81 \%) .{ }^{1} \mathrm{H} \mathrm{NMR}$ $\left(\mathrm{CDCl}_{3}\right) \delta 7.77(\mathrm{~d}, J=2.2 \mathrm{~Hz}, 1 \mathrm{H}), 7.68(\mathrm{~d}, J=8.8 \mathrm{~Hz}, 1 \mathrm{H}), 7.61(\mathrm{dd}, J=8.9,2.2 \mathrm{~Hz}, 1 \mathrm{H}), 7.56(\mathrm{~s}, 1 \mathrm{H})$, $6.09(\mathrm{~s}, 1 \mathrm{H}), 5.66(\mathrm{~s}, 2 \mathrm{H}), 4.07(\mathrm{~s}, 3 \mathrm{H}), 3.99(\mathrm{~s}, 2 \mathrm{H}), 3.82(\mathrm{~s}, 3 \mathrm{H}), 3.81(\mathrm{q}, J=7.1 \mathrm{~Hz}, 2 \mathrm{H}), 3.75(\mathrm{~s}, 3 \mathrm{H})$, $1.25(\mathrm{t}, J=7.1 \mathrm{~Hz}, 3 \mathrm{H}) .{ }^{13} \mathrm{C} \mathrm{NMR}\left(\mathrm{CDCl}_{3}\right) \delta 161.2,157.7,153.9,145.5,144.5,136.4,135.9,132.2,129.3$, $128.8,126.9,125.2,117.3,103.0,90.8,65.7,60.8,54.0,53.8,30.2,15.4$. Found: $[\mathrm{M}+\mathrm{H}]=463.1$. HRMS: calculated for $\mathrm{C}_{21} \mathrm{H}_{23} \mathrm{BrN}_{2} \mathrm{O}_{5}$ : 462.0790; found: 462.0794 .

1-(6-Bromo-2-methoxyquinolin-3-yl)-4-((2,4-dimethoxybenzyl)(methyl)amino)-2-(2,6-dimethoxypyridin-4-yl)-1(2-(ethoxymethoxy)-3,6-dimethoxypyridin-4-yl)butan-2-ol (66). The product was prepared from 65 and 15 using the General Coupling Procedure above. Column chromatography with EtOAc:hexanes (1:1) gave fore fractions, then 66 as a mixture of isomers (59\%), as a yellow foam which were used crude for the next step.. Found: $[\mathrm{M}+\mathrm{H}]=$ 837.2. HRMS: calculated for $\mathrm{C}_{41} \mathrm{H}_{49} \mathrm{BrN}_{4} \mathrm{O}_{10}$ : 836.2632; found: 836.2662.

1-(6-Bromo-2-methoxyquinolin-3-yl)-2-(2,6-dimethoxypyridin-4-yl)-1-(2-(ethoxymethoxy)-3,6-dimethoxypyridin4-yl)-4-(methylamino)butan-2-ol (68). To a solution of $66(0.82 \mathrm{~g}, 0.98 \mathrm{mmol})$ in DCM (10 mL) cooled to $0{ }^{\circ} \mathrm{C}$, triethylamine $(0.30 \mathrm{~mL}, 2.16 \mathrm{mmol})$ and trifluoroacetic anhydride $(0.25 \mathrm{~mL}, 1.96 \mathrm{mmol})$ were added. The reaction mixture was stirred for $20 \mathrm{~min}$, poured onto sat. aq. $\mathrm{NaHCO}_{3}(150 \mathrm{~mL})$, extracted with DCM $(3 \times 20 \mathrm{~mL})$. The combined organic layers were dried over $\mathrm{Na}_{2} \mathrm{SO}_{4}$, filtered and concentrated under reduced pressure to obtain a yellowish residue. The crude material was dissolved in $\mathrm{MeOH}(30 \mathrm{~mL})$ and cooled to $-78{ }^{\circ} \mathrm{C}$. Cesium carbonate $(0.96 \mathrm{~g}, 2.94 \mathrm{mmol})$ was added and the reaction mixture was stirred at $-20^{\circ} \mathrm{C}$ for $48 \mathrm{~h}$. Water $(50 \mathrm{~mL})$ was added to the reaction mixture and extracted with EtOAc $(3 \times 20 \mathrm{~mL})$. The combined organic layers washed with brine $(50 \mathrm{~mL})$, dried over $\mathrm{Na}_{2} \mathrm{SO}_{4}$, filtered and concentrated under reduced pressure to obtain a yellow residue. Column chromatography with EtOAc:MeOH (9:1) gave $68(0.45 \mathrm{~g}, 67 \%)$ as a mixture of isomers. ${ }^{1} \mathrm{H} \mathrm{NMR}$ (DMSO, $400 \mathrm{MHz}) \delta 8.70(\mathrm{~s}, 1 \mathrm{H}), 8.11(\mathrm{~s}, 1 \mathrm{H}), 7.83-7.50(\mathrm{~m}, 6 \mathrm{H}), 7.25-7.22(\mathrm{~m}, 1 \mathrm{H}), 6.64-6.40(\mathrm{~m}, 5 \mathrm{H})$, $5.76(\mathrm{~d}, \mathrm{~J}=6.0 \mathrm{~Hz}, 1 \mathrm{H}), 5.58(\mathrm{~d}, \mathrm{~J}=6.1 \mathrm{~Hz}, 1 \mathrm{H}), 5.51-5.43(\mathrm{~m}, 3 \mathrm{H}), 5.37(\mathrm{~s}, 1 \mathrm{H}), 4.20(\mathrm{~s}, 3 \mathrm{H}), 3.97(\mathrm{~s}, 3 \mathrm{H})$, $3.88(\mathrm{~s}, 6 \mathrm{H}), 3.82-3.78(15 \mathrm{H}), 3.81-3.75(\mathrm{~m}, 2 \mathrm{H}), 3.69-3.62(\mathrm{~m}, 2 \mathrm{H}), 3.42(\mathrm{~s}, 3 \mathrm{H}), 2.62-2.53(\mathrm{~m}, 2 \mathrm{H})$, 2.32-2.22 (m, 2H), $2.23(\mathrm{~s}, 3 \mathrm{H}), 2.16(\mathrm{~s}, 3 \mathrm{H}), 1.91-1.77(\mathrm{~m}, 2 \mathrm{H}), 1.74-1.58(\mathrm{~m}, 2 \mathrm{H}), 1.29-1.23(\mathrm{~m}, 6 \mathrm{H})$ (no $\mathrm{OH}, \mathrm{NH}$ observed). Found: $[\mathrm{M}+\mathrm{H}]=687.2$. HRMS: calculated for $\mathrm{C}_{32} \mathrm{H}_{39} \mathrm{BrN}_{4} \mathrm{O}_{8}$ : 686.1951; found: 686.1960 .

4-(1-(6-Bromo-2-methoxyquinolin-3-yl)-2-(2,6-dimethoxypyridin-4-yl)-2-hydroxy-4-(methylamino)butyl)-3,6dimethoxypyridin-2(1H)-one $(5 \mathrm{C})$. Solution of $68(0.45 \mathrm{~g}, 0.66 \mathrm{mmol})$ in THF $(10 \mathrm{~mL})$ cooled to $0{ }^{\circ} \mathrm{C}$, was added $2 \mathrm{M} \mathrm{HCl}$ in diethyl ether $(1 \mathrm{~mL})$. The reaction mixture was stirred at $0{ }^{\circ} \mathrm{C}$ for $30 \mathrm{~min}$. Water $(15 \mathrm{~mL})$ was added to the reaction mixture and extracted with EtOAc $(3 \times 10 \mathrm{~mL})$. The combined organic layers washed with brine $(10 \mathrm{~mL})$, dried over $\mathrm{Na}_{2} \mathrm{SO}_{4}$, filtered and concentrated under reduced pressure to obtain a yellow residue. Column chromatography with DCM:MeOH (9:1) gave 5C* $(0.23 \mathrm{~g}$, $54 \%$ ) as mixture. ${ }^{1} \mathrm{H}$ NMR (DMSO, $\left.400 \mathrm{MHz}\right) \delta 8.73(\mathrm{~s}, 1 \mathrm{H}), 8.34-8.17(\mathrm{~m}, 3 \mathrm{H}), 7.77-7.63(\mathrm{~m}, 3 \mathrm{H}), 7.53$ $(\mathrm{d}, \mathrm{J}=8.8 \mathrm{~Hz}, 1 \mathrm{H}), 6.87(\mathrm{~s}, 1 \mathrm{H}), 6.45-6.32(\mathrm{~m}, 4 \mathrm{H}), 6.26(\mathrm{~s}, 1 \mathrm{H}), 5.43(\mathrm{~s}, 1 \mathrm{H}), 5.34(\mathrm{~s}, 1 \mathrm{H}), 4.18(\mathrm{~s}, 3 \mathrm{H}), 3.82$ $(\mathrm{s}, 12 \mathrm{H}), 3.73-3.68(\mathrm{~m}, 12 \mathrm{H}), 3.31(\mathrm{~s}, 3 \mathrm{H}), 2.80-2.55(\mathrm{~m}, 2 \mathrm{H}), 2.41-2.05(\mathrm{~m}, 9 \mathrm{H}), 2.00-1.68(3 \mathrm{H})(\mathrm{no} \mathrm{OH}$, 
$\mathrm{NH}$ observed). Found: $[\mathrm{M}+\mathrm{H}]=629.2$. HRMS: calculated for $\mathrm{C}_{29} \mathrm{H}_{33} \mathrm{BrN}_{4} \mathrm{O}_{7}$ : 628.1533; found: 628.1542 .

2-Hydroxy-6-methoxyisonicotinic acid (70). Methyl 2-hydroxy-6-methoxyisonicotinate (3.74 g, $18.0 \mathrm{mmol})$ in MeOH:THF (1:1, $100 \mathrm{~mL})$ was added $\mathrm{LiOH}(1.27 \mathrm{~g}, 53.0 \mathrm{mmol})$ dissolved in water $(50 \mathrm{~mL})$. The reaction mixture was stirred at r.t. for $3 \mathrm{~h}$. The reaction mixture was concentrated under reduced pressure and added water $(50 \mathrm{~mL})$ and extracted with EtOAc $(1 \times 20 \mathrm{~mL})$. The aqueous phase was added $2 \mathrm{M} \mathrm{HCl}$ until $\mathrm{pH}$ was $\sim 1$ which led to formation of white precipitates. The solid was filtered and collected to give $70(3.35 \mathrm{~g}, 94 \%) .{ }^{1} \mathrm{H}$ NMR (DMSO, $\left.400 \mathrm{MHz}\right) \delta 6.59(\mathrm{~s}, 2 \mathrm{H}), 3.82(\mathrm{~s}, 3 \mathrm{H})$. Found: $[\mathrm{M}+\mathrm{H}]=170.2$. HRMS: calculated for $\mathrm{C}_{7} \mathrm{H}_{7} \mathrm{NO}_{4}$ : 169.0375; found: 169.0377 .

2-Hydroxy-N,6-dimethoxy-N-methylisonicotinamide (71). 70 (3.35 g, $19.8 \mathrm{mmol})$ and triethylamine $(9.66 \mathrm{~mL}, 69.3 \mathrm{mmol})$ in DMF $(30 \mathrm{~mL})$ was stirred at room temperature until homogeneous. $\mathrm{N}, \mathrm{O}$-dimethylhydroxylamine hydrochloride $(4.18 \mathrm{~g}, 22.0 \mathrm{mmol})$ and hydroxybenzotriazole $(2.01 \mathrm{~g}$, $14.9 \mathrm{mmol})$ were added and the solution was stirred for $2 \mathrm{~min}$. EDCI.HCl $(4.18 \mathrm{~g}, 22.0 \mathrm{mmol})$ was added and the mixture was stirred at room temperature for $18 \mathrm{~h}$. The solvent was completely removed under reduced pressure and the residue was triturated 3 times with acetone. The combined acetone triturates were concentrated to dryness and the residue was used crude for the next step $(2.94 \mathrm{~g}, 70 \%)$.

N,2-Dimethoxy-6-((4-methoxybenzyl)oxy)-N-methylisonicotinamide (72). A solution of $\mathbf{7 1}$ (2.94 g, $14.0 \mathrm{mmol})$ in DMF (20 mL) was cooled in an ice bath. Sodium hydride $60 \% \mathrm{w} / \mathrm{w}$ in oil $(0.83 \mathrm{~g}, 21.0 \mathrm{mmol})$ was added in portions with stirring over $5 \mathrm{~min}$. 1-(Chloromethyl)-4-methoxybenzene ( $2.28 \mathrm{~mL}, 17.0 \mathrm{mmol}$ ) was then added and the solution was stirred at room temperature for $18 \mathrm{~h}$. The product was partitioned between EtOAc and brine, and the combined organic layers washed with brine $(50 \mathrm{~mL})$, dried over $\mathrm{Na}_{2} \mathrm{SO}_{4}$, filtered and concentrated under reduced pressure to obtain a yellow residue. Column chromatography with hexanes:EtOAc (4:1) gave $72(1.49 \mathrm{~g}, 32 \%) .{ }^{1} \mathrm{H}$ NMR $\left(\mathrm{CDCl}_{3}, 400 \mathrm{MHz}\right) \delta$ 7.40-7.36 (m, 2H), 6.92-6.88 (m, 2H), $6.51(\mathrm{~s}, 1 \mathrm{H}), 6.47(\mathrm{~s}, 1 \mathrm{H}), 5.31(\mathrm{~s}, 2 \mathrm{H}), 3.93(\mathrm{~s}, 3 \mathrm{H}), 3.81(\mathrm{~s}, 3 \mathrm{H}), 3.81$ $(\mathrm{s}, 3 \mathrm{H}), 3.57(\mathrm{~s}, 3 \mathrm{H}), 3.31(\mathrm{~s}, 3 \mathrm{H})$. Found: $[\mathrm{M}+\mathrm{H}]=333.2$. HRMS: calculated for $\mathrm{C}_{17} \mathrm{H}_{20} \mathrm{~N}_{2} \mathrm{O}_{5}$ : 332.1372; found: 332.1380 .

3-((2,4-Dimethoxybenzyl)(methyl)amino)-1-(2-methoxy-6-((4-methoxybenzyl)oxy)pyridin-4-yl)propan-1-one (74). Vinylmagnesium bromide $(8.97 \mathrm{~mL}$ of a $1 \mathrm{~N}$ solution in THF, $8.75 \mathrm{mmol})$ was added to a solution of $72(1.49 \mathrm{~g}, 4.48 \mathrm{mmol})$ in dry THF $(30 \mathrm{~mL})$ at $0{ }^{\circ} \mathrm{C}$. The brown solution was warmed to r.t. for $1 \mathrm{~h}$ then a solution of $\mathrm{N}$-methyl-2,4-dimethoxybenzylamine $\mathbf{1 4}(2.03 \mathrm{~g}, 11.2 \mathrm{mmol})$ in THF $(10 \mathrm{~mL})$, and water $(20 \mathrm{~mL})$ were added. The solution was stirred at r.t. for $20 \mathrm{~min}$, then partitioned between EtOAc and water. The mixture was extracted with EtOAc $(4 \times 20 \mathrm{~mL})$. The solution was dried and evaporated to give a brown oil, which was chromatographed. Elution with EtOAc/hexanes gave fore fractions, then elution with EtOAc gave $74(1.38 \mathrm{~g}, 64 \%)$ as a light yellow oil. ${ }^{1} \mathrm{H} \mathrm{NMR}\left(\mathrm{CDCl}_{3}\right) \delta$ 7.39-7.37 (m, 2H), 7.13-7.10 (m, 1H), 6.92-6.88 (m, 2H), $6.77(\mathrm{~d}, J=1.1 \mathrm{~Hz}, 1 \mathrm{H}), 6.72(\mathrm{~d}, J=1.1 \mathrm{~Hz}, 1 \mathrm{H})$, 6.42-6.40 (m, 2H), $5.32(\mathrm{~s}, 2 \mathrm{H}), 5.29(\mathrm{~s}, 2 \mathrm{H}), 3.95(\mathrm{~s}, 3 \mathrm{H}), 3.81(\mathrm{~s}, 3 \mathrm{H}), 3.78(\mathrm{~s}, 3 \mathrm{H}), 3.76(\mathrm{~s}, 3 \mathrm{H}), 3.10$ $(\mathrm{t}, J=7.0 \mathrm{~Hz}, 2 \mathrm{H}), 2.83(\mathrm{t}, J=7.0 \mathrm{~Hz}, 2 \mathrm{H}), 2.24(\mathrm{~s}, 3 \mathrm{H})$. Found: $[\mathrm{M}+\mathrm{H}]=481.3$. HRMS: calculated for $\mathrm{C}_{27} \mathrm{H}_{32} \mathrm{~N}_{2} \mathrm{O}_{6}$ : 480.2260; found: 480.2272 .

1-(6-Bromo-2-methoxyquinolin-3-yl)-4-((2,4-dimethoxybenzyl)(methyl)amino)-2-(2-methoxy-6-((4-methoxybenzyl) oxy)pyridin-4-yl)-1-(2,3,6-trimethoxypyridin-4-yl)butan-2-ol (75). The product was prepared from 7 and 74 using the General Coupling Procedure above. Column chromatography with EtOAc:hexanes (1:1) gave fore fractions, then 75 as a mixture of isomers $(67 \%)$, as a yellow foam which were used crude for the next step. LRMS: calculated for $\mathrm{C}_{46} \mathrm{H}_{51} \mathrm{BrN}_{4} \mathrm{O}_{10}$ : 898.3; found: $[\mathrm{M}+\mathrm{H}]=899.2$.

1-(6-Bromo-2-methoxyquinolin-3-yl)-2-(2-methoxy-6-((4-methoxybenzyl)oxy)pyridin-4-yl)-4-(methylamino)-1(2,3,6-trimethoxypyridin-4-yl)butan-2-ol (77). To a solution of 75 (1.43 g, $1.59 \mathrm{mmol})$ in DCM (30 mL) cooled to $0{ }^{\circ} \mathrm{C}$, triethylamine $(0.49 \mathrm{~mL}, 3.50 \mathrm{mmol})$ and trifluoroacetic anhydride $(0.44 \mathrm{~mL}, 3.18 \mathrm{mmol})$ were added. The reaction mixture was stirred for $30 \mathrm{~min}$, poured onto sat. aq. $\mathrm{NaHCO}_{3}(150 \mathrm{~mL})$, extracted with DCM $(3 \times 20 \mathrm{~mL})$. The combined organic layers were dried over $\mathrm{Na}_{2} \mathrm{SO}_{4}$, filtered 
and concentrated under reduced pressure to obtain a yellowish residue. The crude material was dissolved in $\mathrm{MeOH}(100 \mathrm{~mL})$ and cooled to $-78^{\circ} \mathrm{C}$. Cesium carbonate $(1.55 \mathrm{~g}, 4.77 \mathrm{mmol})$ was added and the reaction mixture was stirred at $-20^{\circ} \mathrm{C}$ for $27 \mathrm{~h}$. Water $(50 \mathrm{~mL})$ was added to the reaction mixture and extracted with EtOAc $(3 \times 20 \mathrm{~mL})$. The combined organic layers were washed with brine $(50 \mathrm{~mL})$, dried over $\mathrm{Na}_{2} \mathrm{SO}_{4}$, filtered and concentrated under reduced pressure to obtain a yellow residue. Column chromatography with EtOAc: $\mathrm{MeOH}(9: 1)$ gave $77(0.45 \mathrm{~g}, 53 \%)$ as mixture of isomers. ${ }^{1} \mathrm{H} \mathrm{NMR}\left(\mathrm{CDCl}_{3}, 400 \mathrm{MHz}\right) \delta 8.73(\mathrm{~s}, 1 \mathrm{H}), 8.10(\mathrm{~s}, 1 \mathrm{H}), 7.83(\mathrm{dd}, \mathrm{J}=2.1 \mathrm{~Hz}, 2 \mathrm{H}), 7.68-7.50(\mathrm{~m}, 4 \mathrm{H})$, 7.39-7.23 (m, 5H), 6.93-6.84 (m, 4H), 6.62-6.45 (m, 5H), $5.47(\mathrm{~s}, 1 \mathrm{H}), 5.35(\mathrm{~s}, 1 \mathrm{H}), 5.25-5.17(\mathrm{~m}, 4 \mathrm{H}), 4.19$ $(\mathrm{s}, 3 \mathrm{H}), 4.01(\mathrm{~s}, 3 \mathrm{H}), 3.93(\mathrm{~s}, 3 \mathrm{H}), 3.88(\mathrm{~s}, 3 \mathrm{H}), 3.86(\mathrm{~s}, 3 \mathrm{H}), 3.82-3.79(\mathrm{~s}, 18 \mathrm{H}), 3.39(\mathrm{~s}, 3 \mathrm{H}), 2.61-2.49$ $(\mathrm{m}, 2 \mathrm{H}), 2.31-2.21(\mathrm{~m}, 2 \mathrm{H}), 2.19(\mathrm{~s}, 3 \mathrm{H}), 2.12(\mathrm{~s}, 3 \mathrm{H}), 1.86-1.68(\mathrm{~m}, 4 \mathrm{H})(\mathrm{no} \mathrm{OH}, \mathrm{NH}$ observed). Found: $[\mathrm{M}+\mathrm{H}]=749.2$. HRMS: calculated for $\mathrm{C}_{37} \mathrm{H}_{41} \mathrm{BrN}_{4} \mathrm{O}_{8}$ : 748.2108; found: 748.2114.

4-(1-(6-Bromo-2-methoxyquinolin-3-yl)-2-hydroxy-4-(methylamino)-1-(2,3,6-trimethoxypyridin-4-yl)butan-2-yl) -6-methoxypyridin-2-ol (5D). To a solution of $77(0.64 \mathrm{~g}, 0.85 \mathrm{mmol})$ in DCM $(20 \mathrm{~mL})$ cooled to $0{ }^{\circ} \mathrm{C}$, TFA $(5 \mathrm{~mL})$ was added. The reaction mixture was stirred at r.t. for $15 \mathrm{~min}$. The reaction mixture was concentrated under reduced pressure and was washed with sat. $\mathrm{NaHCO}_{3}(30 \mathrm{~mL})$ and extracted with EtOAc $(3 \times 20 \mathrm{~mL})$. Column chromatography with DCM:MeOH $(9: 1)$ gave $5 D^{*}(0.51 \mathrm{~g}, 95 \%)$ as mixture of isomers. ${ }^{1} \mathrm{H}$ NMR $\left(\mathrm{CDCl}_{3}, 400 \mathrm{MHz}\right) \delta 8.69(\mathrm{~s}, 1 \mathrm{H}), 8.15(\mathrm{~s}, 1 \mathrm{H}), 7.81(\mathrm{dd}, \mathrm{J}=10.9,1.9 \mathrm{~Hz}, 2 \mathrm{H})$, 7.66-7.50 (m, 4H), $7.12(\mathrm{~s}, 1 \mathrm{H}), 6.49-6.30(\mathrm{~m}, 3 \mathrm{H}), 5.97(\mathrm{~s}, 2 \mathrm{H}), 5.46(\mathrm{~s}, 1 \mathrm{H}), 5.32(\mathrm{~s}, 1 \mathrm{H}), 4.16(\mathrm{~s}, 3 \mathrm{H}), 3.98$ $(\mathrm{s}, 3 \mathrm{H}), 3.92-3.87(\mathrm{~m}, 6 \mathrm{H}), 3.84-3.78(\mathrm{~m}, 12 \mathrm{H}), 3.74(\mathrm{~s}, 3 \mathrm{H}), 3.40(\mathrm{~s}, 3 \mathrm{H}), 2.69-2.50(\mathrm{~m}, 4 \mathrm{H}), 2.29(\mathrm{~s}, 3 \mathrm{H})$, $2.22(\mathrm{~s}, 3 \mathrm{H}), 2.06-1.70(\mathrm{~m}, 4 \mathrm{H})(\mathrm{no} \mathrm{OH}, \mathrm{NH}$ observed). Found: $[\mathrm{M}+\mathrm{H}]=629.2$. HRMS: calculated for $\mathrm{C}_{29} \mathrm{H}_{33} \mathrm{BrN}_{4} \mathrm{O}_{7}$ : 628.1533; found: 628.1541.

(6-Bromo-2-oxo-1,2-dihydroquinolin-3-yl)boronic acid (81). (6-Bromo-2-methoxyquinolin-3-yl)boronic acid $28(1.0 \mathrm{~g}, 3.56 \mathrm{mmol})$ was dissolved in DMF $(5 \mathrm{~mL})$ and cooled to $0{ }^{\circ} \mathrm{C}$ and $1 \mathrm{M} \mathrm{BBr}_{3}$ solution was added in DCM $(18.0 \mathrm{~mL}, 10.7 \mathrm{mmol})$ dropwise. The reaction mixture was stirred at r.t. for $24 \mathrm{~h}$. The reaction mixture was washed with sat. $\mathrm{NaHCO}_{3}(30 \mathrm{~mL})$ and extracted with EtOAc $(3 \times 20 \mathrm{~mL})$. White precipitates formed in the organic layer which was filtered and collected to give $81(0.862 \mathrm{~g}, 91 \%)$. ${ }^{1} \mathrm{H}$ NMR (DMSO, $\left.400 \mathrm{MHz}\right) \delta 12.27(\mathrm{~s}, 1 \mathrm{H}), 8.83(\mathrm{~d}, J=9.3 \mathrm{~Hz}, 2 \mathrm{H}), 8.40(\mathrm{~s}, 1 \mathrm{H}), 8.06(\mathrm{~d}, J=2.2 \mathrm{~Hz}, 1 \mathrm{H})$, $7.72(\mathrm{dd}, J=8.8,2.3 \mathrm{~Hz}, 1 \mathrm{H}), 7.31(\mathrm{~d}, J=8.8 \mathrm{~Hz}, 1 \mathrm{H})$. Found: $[\mathrm{M}+\mathrm{H}-\mathrm{OH}+\mathrm{MeOH}]=283.0$. HRMS: calculated for $\mathrm{C}_{9} \mathrm{H}_{7} \mathrm{BBrNO}_{3}$ : 266.9702; found: 266.9714 .

(6-Bromo-2-(ethoxymethoxy)quinolin-3-yl)boronic acid (82). To a solution of $\mathbf{8 1}(1.55 \mathrm{~g}, 5.85 \mathrm{mmol})$ in DMF (30 mL, anhydrous) at $0{ }^{\circ} \mathrm{C}$, DIPEA was added $(3.06 \mathrm{~mL}, 17.5 \mathrm{mmol})$. 1-Chloro-2-methoxyethane $(1.38 \mathrm{~g}, 14.6 \mathrm{mmol})$ was then added, and the resultant mixture stirred at r.t. for $48 \mathrm{~h}$. The reaction was diluted with brine $(50 \mathrm{~mL})$ and extracted with EtOAc $(3 \times 20 \mathrm{~mL})$. The combined organic layers washed with brine $(50 \mathrm{~mL})$, dried over $\mathrm{Na}_{2} \mathrm{SO}_{4}$, filtered and concentrated under reduced pressure to obtain a yellow solid. Crude product was triturated with hexanes: $\mathrm{Et}_{2} \mathrm{O}(1: 1)$ mixture and filtered and collected to give 82 as a white solid $(1.31 \mathrm{~g}, 69 \%)$ which was pure enough to be used for the next step. ${ }^{1} \mathrm{H}$ NMR (DMSO, $400 \mathrm{MHz}) \delta 8.69(\mathrm{~s}, 2 \mathrm{H}), 8.42(\mathrm{~s}, 1 \mathrm{H}), 8.12(\mathrm{~d}, J=2.4 \mathrm{~Hz}, 1 \mathrm{H}), 7.83(\mathrm{dd}, J=9.1,2.4 \mathrm{~Hz}, 1 \mathrm{H}), 7.56$ $(\mathrm{d}, J=9.1 \mathrm{~Hz}, 1 \mathrm{H}), 5.73(\mathrm{~s}, 2 \mathrm{H}), 3.55(\mathrm{q}, J=7.1 \mathrm{~Hz}, 2 \mathrm{H}), 1.07(\mathrm{t}, J=7.0 \mathrm{~Hz}, 3 \mathrm{H})$. Found: $[\mathrm{M}+\mathrm{H}-\mathrm{OH}+$ $\mathrm{MeOH}-\mathrm{OH}+\mathrm{MeOH}]=356.1$. HRMS: calculated for $\mathrm{C}_{12} \mathrm{H}_{13} \mathrm{BBrNO}_{4}$ : 325.0121; found: 325.0126 .

6-Bromo-2-(ethoxymethoxy)-3-((2,3,6-trimethoxypyridin-4-yl)methyl)quinolone (83). A mixture of 82 (1.31 g, $4.06 \mathrm{mmol})$, 4-(bromomethyl)-2,3,6-trimethoxypyridine 80 (1.06 g, $4.06 \mathrm{mmol})$ and cesium carbonate $(1.98 \mathrm{~g}, 6.10 \mathrm{mmol})$ in toluene $(40 \mathrm{~mL}$, anhydrous $)$ and DMF $(20 \mathrm{~mL}$, anhydrous $)$ was purged with nitrogen. $\mathrm{Pd}\left(\mathrm{PPh}_{3}\right)_{4}(0.47 \mathrm{~g}, 0.41 \mathrm{mmol})$ was then added, the mixture purged with nitrogen then heated to $55{ }^{\circ} \mathrm{C}$ under nitrogen for $2.5 \mathrm{~h}$. The reaction was partitioned between EtOAc and water and the organic fraction was dried and evaporated. Column chromatography (9:1 hexanes/EtOAc) gave the product $83(1.34 \mathrm{~g}, 71 \%) .{ }^{1} \mathrm{H}$ NMR $\left(\mathrm{CDCl}_{3}\right) \delta 7.57-7.54(\mathrm{~m}, 2 \mathrm{H}), 7.46-7.44(\mathrm{~m}, 1 \mathrm{H}), 7.24(\mathrm{~s}, 1 \mathrm{H})$, $6.14(\mathrm{~s}, 1 \mathrm{H}), 5.77(\mathrm{~s}, 2 \mathrm{H}), 4.00(\mathrm{~s}, 3 \mathrm{H}), 3.91(\mathrm{~s}, 2 \mathrm{H}), 3.86(\mathrm{~s}, 3 \mathrm{H}), 3.75(\mathrm{~s}, 3 \mathrm{H}), 3.65(\mathrm{q}, J=7.0 \mathrm{~Hz}, 2 \mathrm{H})$, $1.19(\mathrm{t}, J=7.1 \mathrm{~Hz}, 3 \mathrm{H}) .{ }^{13} \mathrm{C} \mathrm{NMR}\left(\mathrm{CDCl}_{3}\right) \delta 162.5,158.0,155.8,144.3,137.4,136.0,135.9,132.8,132.8$ 
130.5, 122.3, 117.1, 115.6, 101.4 , 72.6, 64.9, 60.8, 53.9, 53.7, 30.8, 15.3. Found: $[\mathrm{M}+\mathrm{H}]=463.1$. HRMS: calculated for $\mathrm{C}_{21} \mathrm{H}_{23} \mathrm{BrN}_{2} \mathrm{O}_{5}$ : 462.0790; found: 462.0798 .

1-(6-Bromo-2-(ethoxymethoxy)quinolin-3-yl)-4-((2,4-dimethoxybenzyl)(methyl)amino)-2-(2,6-dimethoxypyridin4-yl)-1-(2,3,6-trimethoxypyridin-4-yl)butan-2-ol (84). The product was prepared from $\mathbf{8 3}$ and $\mathbf{1 5}$ using the General Coupling Procedure below. Column chromatography with EtOAc:hexanes (1:1) gave fore fractions, then $\mathbf{8 4}$ as a mixture of isomers (53\%), as a yellow foam which were used crude for the next step. LRMS: calculated for $\mathrm{C}_{41} \mathrm{H}_{49} \mathrm{BrN}_{4} \mathrm{O}_{10}$ : 836.3; found: $[\mathrm{M}+\mathrm{H}]=837.3$.

1-(6-Bromo-2-(ethoxymethoxy)quinolin-3-yl)-2-(2,6-dimethoxypyridin-4-yl)-4-(methylamino)-1-(2,3,6trimethoxypyridin-4-yl)butan-2-ol (86). To a solution of $84(0.78 \mathrm{~g}, 0.93 \mathrm{mmol})$ in DCM (30 mL) cooled to $0{ }^{\circ} \mathrm{C}$, was added triethylamine $(0.28 \mathrm{~mL}, 2.04 \mathrm{mmol})$ and trifluoroacetic anhydride $(0.26 \mathrm{~mL}, 1.85 \mathrm{mmol})$. The reaction mixture was stirred for $30 \mathrm{~min}$, poured onto sat. aq. $\mathrm{NaHCO}_{3}(150 \mathrm{~mL})$, extracted with $\mathrm{DCM}(3 \times 20 \mathrm{~mL})$. The combined organic layers were dried over $\mathrm{Na}_{2} \mathrm{SO}_{4}$, filtered and concentrated under reduced pressure to obtain a yellowish residue. The crude material was dissolved in $\mathrm{MeOH}$ $(100 \mathrm{~mL})$ and cooled to $-78{ }^{\circ} \mathrm{C}$. Cesium carbonate $(0.91 \mathrm{~g}, 2.78 \mathrm{mmol})$ was added and the reaction mixture was stirred at $-20^{\circ} \mathrm{C}$ for $27 \mathrm{~h}$. Reaction mixture was added water $(50 \mathrm{~mL})$ and extracted with EtOAc $(3 \times 20 \mathrm{~mL})$. The combined organic layers washed with brine $(50 \mathrm{~mL})$, dried over $\mathrm{Na}_{2} \mathrm{SO}_{4}$, filtered and concentrated under reduced pressure to obtain a yellow residue. Column chromatography with EtOAc:MeOH (9:1) gave $86(0.402 \mathrm{~g}, 63 \%)$ as a mixture of isomers. ${ }^{1} \mathrm{H}$ NMR (DMSO, $\left.400 \mathrm{MHz}\right) \delta$ $8.38(\mathrm{~s}, 1 \mathrm{H}), 7.82(\mathrm{~s}, 1 \mathrm{H}), 7.68-7.40(\mathrm{~m}, 6 \mathrm{H}), 7.32-7.24(\mathrm{~m}, 1 \mathrm{H}), 7.13(\mathrm{~s}, 1 \mathrm{H}), 6.65-6.41(\mathrm{~m}, 4 \mathrm{H}), 5.87-5.77$ $(\mathrm{m}, 2 \mathrm{H}), 5.73-5.66(\mathrm{~m}, 2 \mathrm{H}), 5.54-5.43(\mathrm{~m}, 2 \mathrm{H}), 4.03(\mathrm{~s}, 3 \mathrm{H}), 4.00(\mathrm{~s}, 3 \mathrm{H}), 3.76-3.70(\mathrm{~m}, 21 \mathrm{H}), 3.71-3.64$ $(\mathrm{m}, 2 \mathrm{H}), 3.58(\mathrm{~s}, 3 \mathrm{H}), 3.43-3.32(\mathrm{~m}, 2 \mathrm{H}), 2.64-2.51(\mathrm{~m}, 2 \mathrm{H}), 2.41-2.26(\mathrm{~m}, 2 \mathrm{H}), 2.23(\mathrm{~s}, 3 \mathrm{H}), 2.21(\mathrm{~s}, 3 \mathrm{H})$, 2.08-1.92 (m, 2H), 1.82-1.70 (m, 2H), 1.23-1.17 (m, 3H), 1.09-1.06 (m, 3H). (no OH, NH observed). Found: $[\mathrm{M}+\mathrm{H}]=687.2$. HRMS: calculated for $\mathrm{C}_{32} \mathrm{H}_{39} \mathrm{BrN}_{4} \mathrm{O}_{8}$ : 686.1951; found: 686.1964.

6-Bromo-3-(2-(2,6-dimethoxypyridin-4-yl)-2-hydroxy-4-(methylamino)-1-(2,3,6-trimethoxypyridin-4-yl) butyl)quinolin-2(1H)-one (5E). Solution of $86(0.174 \mathrm{~g}, 0.25 \mathrm{mmol})$ in DCM $(60 \mathrm{~mL})$ cooled to $-78^{\circ} \mathrm{C}$, was added $1 \mathrm{M} \mathrm{BBr}_{3}$ solution in $\mathrm{DCM}(0.76 \mathrm{~mL}, 0.76 \mathrm{mmol})$. The reaction mixture was stirred at $-78{ }^{\circ} \mathrm{C}$ for $4 \mathrm{~h}$, followed by $-20^{\circ} \mathrm{C}$ for $72 \mathrm{~h}$. $\mathrm{MeOH}(20 \mathrm{~mL})$ was added to the reaction mixture, and concentrated under reduced pressure. Crude product was initially purified with column chromatography with $\mathrm{DCM}: \mathrm{MeOH}(9: 1)$ which was further purified using preparative supercritical fluid chromatography to give $5 \mathrm{E}^{*}(0.022 \mathrm{~g}, 14 \%) .{ }^{1} \mathrm{H} \mathrm{NMR}\left(\mathrm{CDCl}_{3}, 400 \mathrm{MHz}\right) \delta 8.53(\mathrm{~s}, 1 \mathrm{H}), 7.93(\mathrm{~s}, 1 \mathrm{H})$, 7.71-7.46 (m, 4H), 7.22-6.98 (m, 2H), 6.94-6.89 (m, 1H), 6.72-6.21 (m, 5H), $5.39(\mathrm{~s}, 1 \mathrm{H}), 5.37(\mathrm{~s}, 1 \mathrm{H}), 4.10$ $(\mathrm{s}, 3 \mathrm{H}), 4.02(\mathrm{~s}, 3 \mathrm{H}), 3.90(\mathrm{~s}, 6 \mathrm{H}), 3.86(\mathrm{~s}, 6 \mathrm{H}), 3.84(\mathrm{~s}, 3 \mathrm{H}), 3.80(\mathrm{~s}, 3 \mathrm{H}), 3.79(\mathrm{~s}, 3 \mathrm{H}), 3.56(\mathrm{~s}, 3 \mathrm{H}), 2.89-2.46$ $(\mathrm{m}, 4 \mathrm{H}), 2.38(\mathrm{~s}, 3 \mathrm{H}), 2.24(\mathrm{~s}, 3 \mathrm{H}), 2.15-1.67(\mathrm{~m}, 4 \mathrm{H})(\mathrm{no} \mathrm{OH}, \mathrm{NH}$ observed). Found: $[\mathrm{M}+\mathrm{H}]=629.2$. HRMS: calculated for $\mathrm{C}_{29} \mathrm{H}_{33} \mathrm{BrN}_{4} \mathrm{O}_{7}$ : 628.1533; found: 628.1504 .

${ }^{*}$ The final DARQ compounds 3, 4, 5A, 5B, 5C, 5D, 5E were resolved into four optical isomers using preparative supercritical fluid HPLC at BioDuro LLC (Beijing). The ${ }^{1} \mathrm{H}$ NMR and ${ }^{13} \mathrm{C}$ NMR spectra of key compounds are available in the Supplementary Materials.

\section{Conclusions}

Bedaquiline (1) - targeting the ATP synthase enzyme in the electron transport chain of Mycobacterium tuberculosis-is a key drug for the treatment of drug-resistant tuberculosis. Second generation analogue TBAJ-876 [24] 2 show much promise, with better potency and less hERG liability than bedaquiline. In an effort to aid the preclinical development of 2 , we set out to synthesize its major known desmethyl metabolites. We synthesized and fully characterised seven of these (metabolites 3 , 4 and $5 \mathrm{~A}-5 \mathrm{E}$ ). This work has unequivocally identified and assigned the possible structures of major metabolites of TBAJ-876, and has provided quantities of these as authentic standards for further mass spectrometry and metabolite profiling studies. This will aid in the preclinical development of $\mathbf{2}$ as a potential second generation analogue of bedaquiline. 
Supplementary Materials: The ${ }^{1} \mathrm{H}$ NMR and ${ }^{13} \mathrm{C}$ NMR spectra of key compounds are available online.

Author Contributions: P.J.C. synthetic route design, chemical syntheses of targeted metabolites and manuscript preparation. D.C. provided synthetic route design and chemical synthesis of metabolite 3. H.S.S., A.B., A.S.T.T. provided chemical synthesis of intermediates and characterization. B.D.P., C.B.C. and W.A.D. data analysis and manuscript review. A.M.U. provided biological data. All authors have read and agreed to the published version of the manuscript.

Funding: This work was supported by the Bill \& Melinda Gates Foundation (\#OPP1017459), the U.S. Agency for International Development (USAID), the U.K. Department for International Development (DFID), the Directorate General for International Cooperation of the Netherlands (DGIS), and Irish Aid.

Acknowledgments: Our thanks to BioDuro LLC (Beijing) for the separation of final metabolites into single diastereomer.

Conflicts of Interest: The authors declare no conflict of interest.

\section{References}

1. World Health Organization. Global Tuberculosis Report 2019; Document WHO/HTM/TB/2019; World Health Organization: Geneva, Switzerland, 2019.

2. Sreeramareddy, C.T.; Panduru, K.V.; Menten, J.; Van den Ende, J. Time delays in diagnosis of pulmonary tuberculosis: A systematic review of literature. BMC Infect. Dis. 2009, 9, 91. [CrossRef] [PubMed]

3. Koul, A.; Dendouga, N.; Vergauwen, K.; Molenberghs, B.; Vranckx, L.; Willebrords, R.; Ristic, Z.; Lill, H.; Dorange, I.; Guillemont, J.; et al. Diarylquinolines target subunit c of mycobacterial ATP synthase. Nat. Chem. Biol. 2007, 3, 323-324. [CrossRef]

4. Rustomjee, R.; Diacon, A.H.; Allen, J.; Venter, A.; Reddy, C.; Patientia, R.F.; Mthiyane, T.C.P.; De Marez, T.; van Heeswijk, R.; Kerstens, R.; et al. Early bactericidal activity and pharmacokinetics of the diarylquinoline TMC207 in treatment of pulmonary tuberculosis. Antimicrob. Agents Chemother. 2008, 52, 2831-2835. [CrossRef] [PubMed]

5. Diacon, A.H.; Pym, A.; Grobusch, M.P.; de los Rios, J.M.; Gotuzzo, E.; Vasilyeva, I.; Leimane, V.; Andries, K.; Bakare, N.; De Marez, T. Multidrug-resistant tuberculosis and culture conversion with bedaquiline. N. Engl. J. Med. 2014, 371, 723-732. [CrossRef] [PubMed]

6. Guillemont, J.; Meyer, C.; Poncelet, A.; Bourdrez, X.; Andries, K. Diarylquinolines, synthesis pathways and quantitative structure-activity relationship studies leading to the discovery of TMC207. Future Med. Chem. 2011, 3, 1345-1360. [CrossRef]

7. Svensson, E.M.; Murray, S.; Karlsson, M.O.; Dooley, K.E. Rifampicin and rifapentine significantly reduce concentrations of bedaquiline, a new anti-TB drug. J. Antimicrob. Chemother. 2015, 70, 1106-1114. [CrossRef]

8. Kakkar, A.K.; Dahiya, N. Bedaquiline for the treatment of resistant tuberculosis: Promises and pitfalls. Tuberculosis 2014, 94, 357-362. [CrossRef]

9. World Health Organization. The Use of Bedaquiline in the Reatment of Multidrug-Resistant Tuberculosis. Interim Policy Guidance; Document WHO/HTM/TB/2013.6; World Health Organization: Geneva, Switzerland, 2013.

10. Choi, P.J.; Sutherland, H.S.; Tong, A.S.T.; Blaser, A.; Franzblau, S.G.; Cooper, C.B.; Lotlikar, M.U.; Upton, A.M.; Guillemont, J.; Motte, M.; et al. Synthesis and evaluation of analogues of the tuberculosis drug bedaquiline containing heterocyclic B-ring units. Bioorg. Med. Chem. Lett. 2017, 27, 5190-5196. [CrossRef] [PubMed]

11. Tong, A.S.T.; Choi, P.J.; Blaser, A.; Sutherland, H.S.; Tsang, S.K.Y.; Guillemont, J.; Motte, M.; Cooper, C.B.; Andries, K.; Van den Broeck, W.; et al. 6-Cyano Analogues of Bedaquiline as Less Lipophilic and Potentially Safer Diarylquinolines for Tuberculosis. ACS Med. Chem. Lett. 2017, 8, 1019-1024. [CrossRef] [PubMed]

12. Sutherland, H.S.; Tong, A.S.T.; Choi, P.J.; Conole, D.; Blaser, A.; Franzblau, S.G.; Cooper, C.B.; Upton, A.M.; Lotlikar, M.U.; Denny, W.A.; et al. Structure-activity relationships for analogs of the tuberculosis drug bedaquiline with the naphthalene unit replaced by bicyclic heterocycles. Bioorg. Med. Chem. 2018, 26, 1797-1809. [CrossRef]

13. Blaser, A.; Sutherland, H.S.; Tong, A.S.T.; Choi, P.J.; Conole, D.; Franzblau, S.G.; Cooper, C.B.; Upton, A.M.; Lotlikar, M.; Denny, W.A.; et al. Structure-activity relationships for unit C pyridyl analogues of the tuberculosis drug bedaquiline. Bioorg. Med. Chem. 2019, 27, 1283-1291. [CrossRef] 
14. Sutherland, H.S.; Tong, A.S.T.; Choi, P.J.; Blaser, A.; Conole, D.; Franzblau, S.G.; Lotlikar, M.U.; Cooper, C.B.; Upton, A.M.; Denny, W.A.; et al. 3,5-Dialkoxypyridine analogues of bedaquiline are potent antituberculosis agents with minimal inhibition of the hERG channel. Bioorg. Med. Chem. 2019, 27, 1292-1307. [CrossRef] [PubMed]

15. Sutherland, H.S.; Tong, A.S.T.; Choi, P.J.; Blaser, A.; Franzblau, S.G.; Cooper, C.B.; Upton, A.M.; Lotlikar, M.; Denny, W.A.; Palmer, B.D. Variations in the C-unit of bedaquiline provides analogues with improved biology and pharmacology. Bioorg. Med. Chem. 2020, 28, 115213. [CrossRef] [PubMed]

16. Sarathy, J.P.; Ragunathan, P.; Shin, J.; Cooper, C.B.; Upton, A.M.; Grüber, G.; Dick, T. TBAJ-876 Retains Bedaquiline's Activity against Subunits $\mathrm{c}$ and $\varepsilon$ of Mycobacterium tuberculosis F-ATP Synthase Antimicrob. Agents Chemother. 2019, 63, e01191-19. [CrossRef] [PubMed]

17. Kong, D.-L.; Huang, Y.; Ren, L.-Y.; Feng, W.-H. A highly efficient way to recycle inactive stereoisomers of Bedaquiline into two previous intermediates via base-catalyzed Csp3Csp3 bond cleavage. Chin. Chem. Lett. 2015, 26, 790-792. [CrossRef]

18. Trost, B.M.; Fandrick, D.R. DYKAT of Vinyl Aziridines: Total Synthesis of (+)-Pseudodistomin D. Org. Lett. 2005, 7, 823-826. [CrossRef]

19. Stockmann, V.; Kaspersen, S.J.; Nicolaisen, A.; Fiksdahl, A. Studies on Reactive Pyridylketones Formed by Weinreb Transformations. J. Heterocycl. Chem. 2012, 49, 613-620. [CrossRef]

20. Soni, A.; Dutt, A.; Sattigeri, V.; Cliffe, I.A. Efficient and Selective Demethylation of Heteroaryl Methyl Ethers in the Presence of Aryl Methyl Ethers. Synth. Commun. 2011, 41, 1852-1857. [CrossRef]

21. Hopkins, G.; Jonak, J.; Minnemeyer, H.; Tieckelmann, H. Alkylations of Heterocyclic Ambident Anions II. Alkylation of 2-Pyridone Salts. J. Org. Chem. 1967, 32, 4040-4044. [CrossRef]

22. Upton, A.M.; Cooper, C.B.; Marcel, K.J.L.; Guillemont, J.E.G.; Van Den Broeck, W.M.M.; Palmer, B.D.; Ma, Z. Preparation of Quinoline Compounds as Antibacterial Agents and Uses Thereof. WO2017155909A1, 14 September 2017.

23. Mahiout, Z.; Lomberget, T.; Goncalves, S.; Barret, R. Solvent-dependent oxidations of 5- and 6-azaindoles to trioxopyrrolopyridines and functionalised azaindoles. Org. Biomol. Chem. 2008, 6, 1364-1376. [CrossRef] [PubMed]

24. Global Alliance for TB Drug Development Website. Available online: https://www.tballiance.org/portfolio/ comp2ound/tbaj-876 (accessed on 16 January 2019).

Sample Availability: Samples of compounds 24, 28, 36, 81 are available from the authors.

(C) 2020 by the authors. Licensee MDPI, Basel, Switzerland. This article is an open access article distributed under the terms and conditions of the Creative Commons Attribution (CC BY) license (http://creativecommons.org/licenses/by/4.0/). 